\title{
Switching Site Reactivity in Hydrogenase Model Systems by Introducing a Pendant Amine Ligand
}

\author{
Indresh Kumar Pandey, Tashika Agarwal, Shaikh M. Mobin, Matthias Stein,* \\ and Sandeep Kaur-Ghumaan*
}

Cite This: ACS Omega 2021, 6, 4192-4203

Read Online

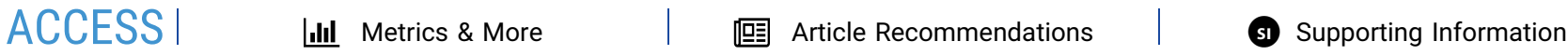

ABSTRACT: Hydrogenases are versatile enzymatic catalysts with an unmet hydrogen evolution reactivity (HER) from synthetic bio-inspired systems. The binuclear active site only has one-site reactivity of the distal $\mathrm{Fe}_{\mathrm{d}}$ atom. Here, binuclear complexes $\left[\mathrm{Fe}_{2}(\mathrm{CO})_{5}(\mu\right.$-Mebdt $\left.)\left(\mathrm{P}\left(4-\mathrm{C}_{6} \mathrm{H}_{4} \mathrm{OCH}_{3}\right)_{3}\right)\right] 1$ and $\left[\mathrm{Fe}_{2}(\mathrm{CO})_{5}(\mu\right.$-Mebdt $\left.)\left(\mathrm{PPh}_{2} \mathrm{Py}\right)\right] 2$ are presented, which show electrocatalytic activity in the presence of weak acids as a proton source for the HER. Despite almost identical structural and spectroscopic properties (bond distances and angles from single-crystal X-ray; IR, UV/vis, and NMR), introduction of a nitrogen base atom in the phosphine ligand in 2 markedly changes site reactivity. The bridging benzenedithiolate ligand Mebdt interacts with the terminal ligand's phenyl aromatic rings and stabilizes the reduced states of the catalysts. Although 1 with monodentate phosphine terminal ligands only shows a distal iron atom HER activity by a sequence of electrochemical and protonation steps, the lone pair of pyridine nitrogen in $\mathbf{2}$ acts as the primary site of protonation. This swaps the

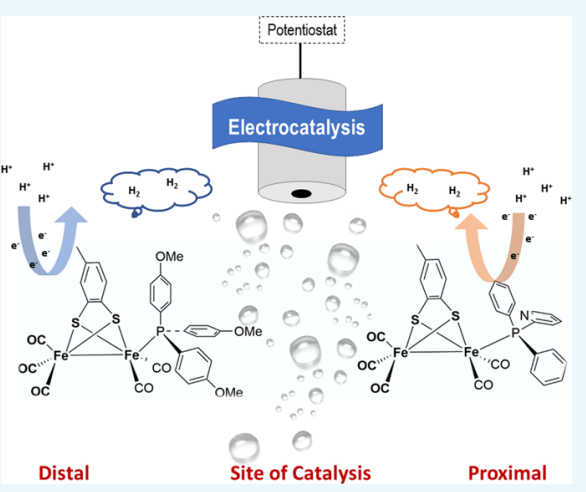
iron atom catalytic activity toward the proximal iron for complex 2. Density-functional theory (DFT) calculations reveal the role of terminal phosphines ligands without/with pendant amines by directing the proton transfer steps. The reactivity of $\mathbf{1}$ is a thiol-based protonation of a dangling bond in $\mathbf{1}^{-}$and distal iron hydride mechanism, which may follow either an ECEC or EECC sequence, depending on the choice of acid. The pendant amine in 2 enables a terminal ligand protonation and an ECEC reactivity. The introduction of a terminal nitrogen atom enables the control of site reactivity in a binuclear system.

\section{INTRODUCTION}

$[\mathrm{FeFe}]$ hydrogenase enzymes are highly efficient catalysts with a turnover frequency (TOF) exceeding $6000 \mathrm{~s}^{-1}$ at an electrochemical potential close to the thermodynamic limit for the process of hydrogen generation. ${ }^{1,2}$

Initial crystal structures ${ }^{3,4}$ of the enzyme were unable to unambiguously identify the nature of the central atom of the bridging dithiolate ligand. ${ }^{14} \mathrm{~N}-\mathrm{HYSCORE}$ investigations indicated the possibility of an amine, ${ }^{5}$ but a final assignment was only possible from structural $[\mathrm{FeFe}]$ model complexes with a well-designed coordination environment. ${ }^{6,7}$ The $\mathrm{NH}$ group is thought to be favoring the proton reduction process by serving as a proton shuttle to the diiron subsite, thereby assisting in the formation of a key intermediate that involves hydrido-proton interaction. ${ }^{8}$ Later, the azadithiolate was also resolved in high-resolution protein X-ray structures. ${ }^{9,10}$ While the active site $\mathrm{H}$-cluster is a diiron subsite coordinated by small inorganic $\mathrm{CO}$ and $\mathrm{CN}$ ligands and is connected to a [4Fe-4S] cubane cluster, only the iron atom distal to the cubane $\left(\mathrm{Fe}_{\mathrm{d}}\right)$ is involved in a proton reduction mechanism to release $\mathrm{H}_{2}$ (Figure 1).

The mechanism of the enzymatic hydrogen evolution reaction (HER) has been thoroughly reviewed in the literature. ${ }^{2,4,11-13}$

The approaches to design bio-inspired model complexes have been extensively studied in several articles. ${ }^{14-16}$ In particular, the balance between sites of protonation and hydride reactivity is discussed. A large number of complexes have been investigated with either a pendant amine in the dithiolate-bridged adt complexes, $-\mathrm{NH}$ or $-\mathrm{NR}(\mathrm{R}=$ different

Received: October 7, 2020

Accepted: December 24, 2020

Published: February 2, 2021

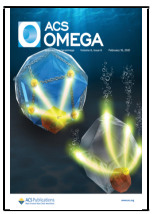




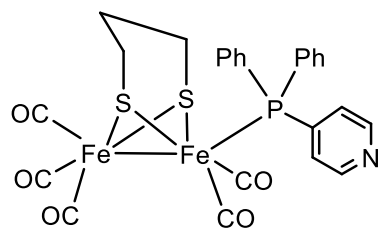

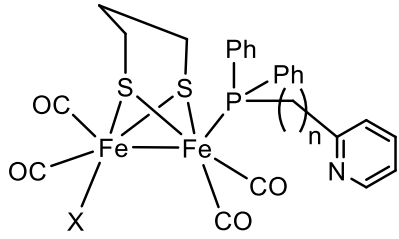<smiles>O=C1CCSC(C(=O)[O-])(P(=O)(Nc2ccncc2)P(=O)([O-])c2ccccc2)S1</smiles>

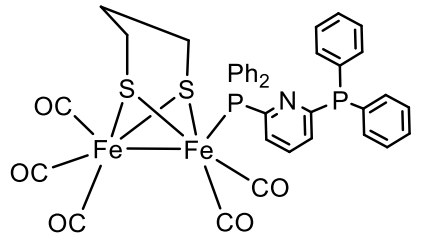

$\mathrm{n}=0,1 ; \mathrm{X}=\mathrm{CO}, \mathrm{PMe}_{3}$

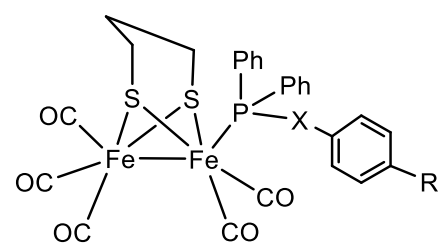

$$
\mathrm{X}=\mathrm{CH}_{2} ; \mathrm{R}=\mathrm{H}
$$

$\mathrm{X}=\mathrm{NH} ; \mathrm{R}=\mathrm{H}, \mathrm{Me}, \mathrm{OMe}, \mathrm{CO}_{2} \mathrm{Me}, \mathrm{Br}$

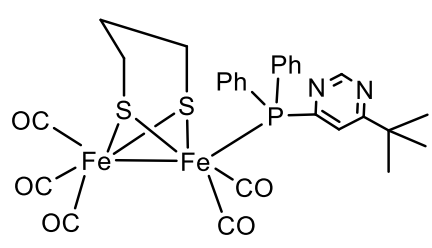

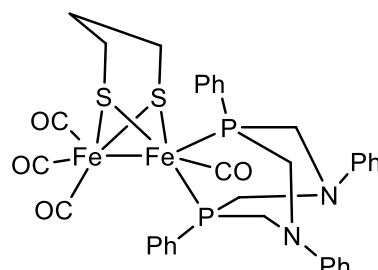

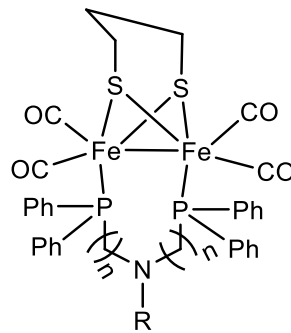
$\mathrm{n}=0 ; \mathrm{R}=\mathrm{H}, n-\mathrm{Pr}, n-\mathrm{Bu}$, allyl $\mathrm{n}=1 ; \mathrm{R}=n-\mathrm{Pr}$

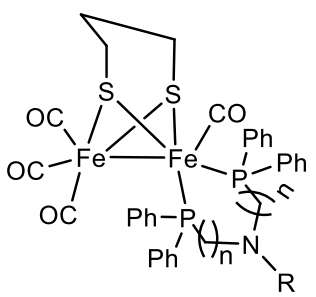

$$
\begin{gathered}
\mathrm{n}=0 ; \mathrm{R}=\mathrm{H}, \mathrm{Me}, \mathrm{Et}, n-\mathrm{Pr}, n-\mathrm{Bu}, \\
\text { allyl, } p \text {-tosyl, } \mathrm{C}_{6} \mathrm{H}_{4} \mathrm{Me}-p \\
\mathrm{n}=1 ; \mathrm{R}=\mathrm{Me}, n-\mathrm{Pr}
\end{gathered}
$$

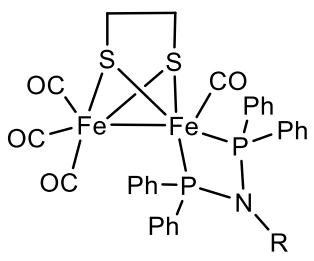

$\mathrm{R}=\mathrm{CMe}_{3},\left(\mathrm{CH}_{2}\right)_{2} \mathrm{CHMe}_{2},\left(\mathrm{CH}_{2}\right)_{3} \mathrm{Me}$, $\left(\mathrm{CH}_{2}\right)_{3} \mathrm{OMe},\left(\mathrm{CH}_{2}\right)_{3} \mathrm{SMe},\left(\mathrm{CH}_{2}\right)_{3} \mathrm{NMe}_{2}$, $\left(\mathrm{CH}_{2}\right)_{3} \mathrm{Si}(\mathrm{OEt})_{3}$

Figure 2. Diiron carbonyl complexes with pendant amines.

groups), or terminal pendant amines to substitute one or more carbonyl ligand(s) (some selected examples are shown in Figure 2), ${ }^{17-41}$ most of which display alkyl dithiolate bridging ligands. Incorporation of a basic terminal nitrogen-containing ligand can assist proton transfer to the nearest metal ion. ${ }^{38}$ When introducing larger bridging aromatic thiolate ligands ${ }^{42,43}$ and/or terminal nitrogen-containing ligands, ${ }^{44,45}$ a pronounced effect on redox potential and a catalyst stabilization by $\pi-\pi$ stacking of the bridging and a terminal aromate can be seen. ${ }^{46}$

Herein, we present two complexes $\left[\mathrm{Fe}_{2}(\mathrm{CO})_{5}(\mu\right.$-Mebdt $)$ $\left.\left(\mathrm{P}\left(4-\mathrm{C}_{6} \mathrm{H}_{4} \mathrm{OCH}_{3}\right)_{3}\right)\right] \mathbf{1}$ and $\left[\mathrm{Fe}_{2}(\mathrm{CO})_{5}(\mu-\mathrm{Mebdt})\left(\mathrm{PPh}_{2} \mathrm{Py}\right)\right]$ 2, $\left(\mathrm{P}\left(4-\mathrm{C}_{6} \mathrm{H}_{4} \mathrm{OCH}_{3}\right)_{3}=\operatorname{tris}\right.$ (4-methoxyphenyl)phosphine, $\mathrm{PPh}_{2} \mathrm{Py}=$ diphenyl-2-pyridylphosphine) with identical primary coordination environments consisting of a $(\mathrm{CO})_{3} \mathrm{Fe}(\mathrm{I}) \mathrm{Fe}(\mathrm{I})$ $\left(\mathrm{PX}_{3}\right)$ core with a 3,4-toluenedithiolate $(\mu$-Mebdt) bridging aromatic dithiolate ligand and terminal phosphine ligands $\left(\mathrm{PX}_{3}\right)$. Complex 2 only differs in the secondary coordination environment in that the methoxyphenyl groups are substituted by two aromatic phenyl and one pyridine ligand.

Complexes $\mathbf{1}$ and $\mathbf{2}$ are investigated for their respective ability to catalyze the proton-assisted hydrogen evolution reaction. The electrochemical behavior of complexes 1 and 2 on treatment with acids $\left(\mathrm{CH}_{3} \mathrm{CO}_{2} \mathrm{H}, \mathrm{CF}_{3} \mathrm{CO}_{2} \mathrm{H}\right.$, and $\left.\mathrm{HClO}_{4}\right)$ and the effect of the presence of phosphine ligands without and with a pendant amine are discussed. Although both complexes $\mathbf{1}$ and $\mathbf{2}$ are very similar spectroscopically and electrochemically, the quantum chemically suggested reaction mechanisms are strikingly different. Upon one-electron reduction, in the tris(4-methoxyphenyl) terminal phosphine-substituted diiron complex $\mathbf{1}$, an elongation of one $\mathrm{Fe}-\mathrm{S}$ bond occurs, which enables thiolate protonation and hydrogen evolution involving the distal iron atom. Both ECEC and EECC mechanisms appear feasible and may be controlled by the strength $\left(\mathrm{p} K_{\mathrm{a}}\right)$ of a given acid. Strong acids have been reported to promote an ECEC pathway in comparison to an EECC pathway promoted by weak acids. In the catalytic cycle, the subsequent $\mathrm{E}$ or $\mathrm{C}$ step that follows the first $\mathrm{E}$ step is determined based on the $\mathrm{p} K_{\mathrm{a}}$ values of the first reduced intermediate formed and that of the acid used as a proton source.

In the case of complex 2 , with a pyridyl group in the phosphine ligand, the one-electron reduction is partially ligandbased and enables protonation of the lone pair of the nitrogen atom as the first step. A proton transfer to the proximal atom affords a reactive terminal hydride and is accompanied by a concerted ligand rotation. By changing the second coordination sphere ligands and introducing a peripheral site of protonation, one can thus control the site reactivity of a binuclear iron catalyst. 
(a)

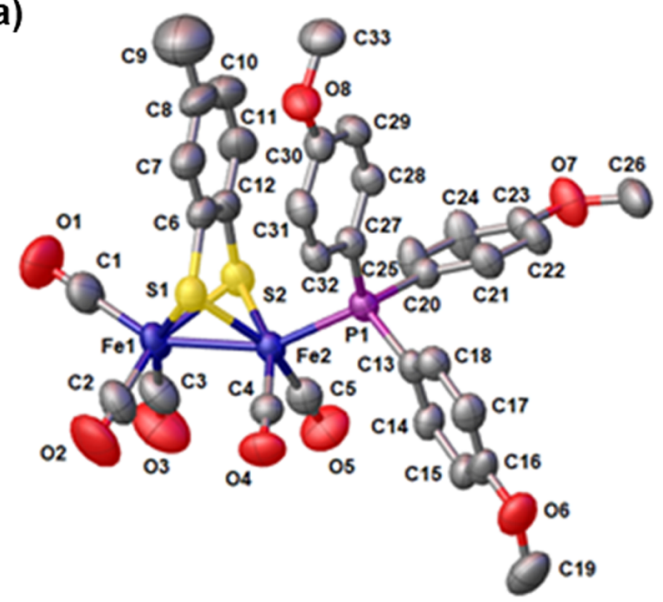

(b)

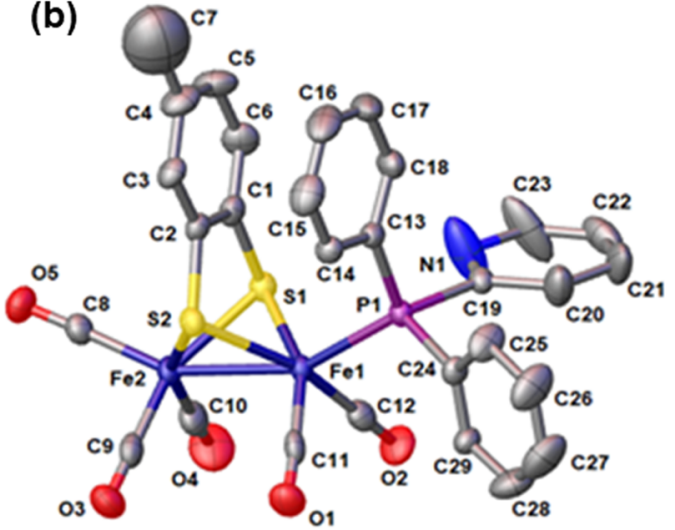

Figure 3. Crystal structures of $(\mathrm{a})\left[\mathrm{Fe}_{2}(\mathrm{CO})_{5}(\mu\right.$-Mebdt $\left.)\left(\mathrm{P}\left(4-\mathrm{C}_{6} \mathrm{H}_{4} \mathrm{OCH}_{3}\right)_{3}\right)\right] \mathbf{1}$ and $(\mathrm{b})\left[\mathrm{Fe}_{2}(\mathrm{CO})_{5}(\mu\right.$-Mebdt $\left.)\left(\mathrm{PPh}{ }_{2} \mathrm{Py}\right)\right]$ 2. Hydrogen atoms have been omitted for clarity.

Table 1. Comparison of Relevant Experimental Structural Data for Complexes 1 and 2 with Calculated Data (BP86D3) ${ }^{a}$

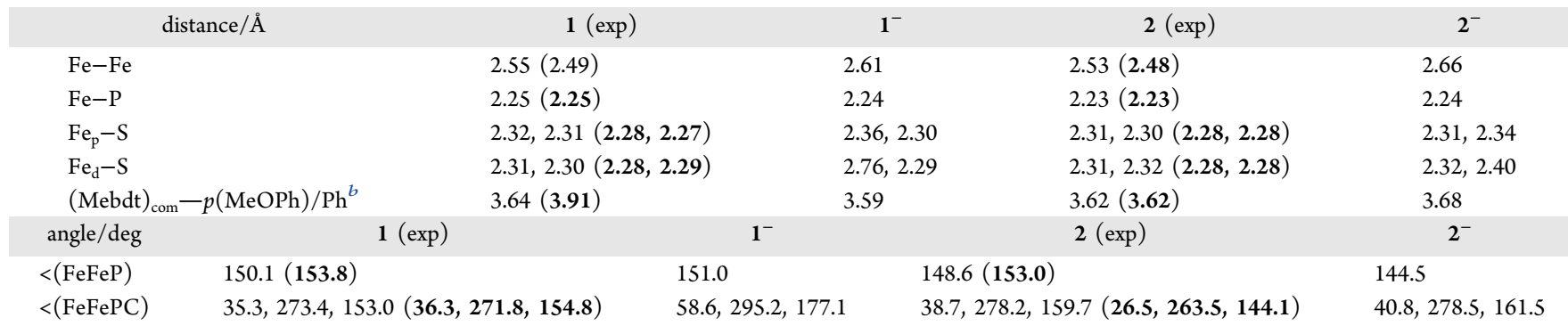

${ }^{a}$ Additional calculated values are given for the mono-reduced forms to discuss structural changes. The values in parentheses are from X-ray crystallography. ${ }^{b}$ Center-of-mass-to-center-of-mass distance between bridging Mebdt aromatic ring and terminal phosphine aromatic ligand in apical position.

\section{RESULTS AND DISCUSSION}

Preparation and Crystallographic Characterization. The precursor complex $\left[\mathrm{Fe}_{2}(\mathrm{CO})_{6}(\mu\right.$-Mebdt $\left.)\right]$ was synthesized as reported in the literature. ${ }^{47}$ The target complexes $\left[\mathrm{Fe}_{2}(\mathrm{CO})_{5}(\mu-\mathrm{Mebdt})\left(\mathrm{P}\left(4-\mathrm{C}_{6} \mathrm{H}_{4} \mathrm{OCH}_{3}\right)_{3}\right)\right] \mathbf{1}$ and $\left[\mathrm{Fe}_{2}(\mathrm{CO})_{5}(\mu\right.$-Mebdt $\left.)\left(\mathrm{PPh}_{2} \mathrm{Py}\right)\right] 2$ were then prepared by reaction of the precursor complex with the monodentate phosphine ligands $\mathrm{P}\left(4-\mathrm{C}_{6} \mathrm{H}_{4} \mathrm{OCH}_{3}\right)_{3}$ and $\mathrm{PPh}_{2} \mathrm{Py}$ using standard Schlenck line techniques with toluene as the solvent (Scheme S1, see Supporting Information, SI). The complexes were then purified by column chromatography and recrystallized from $n$-hexane-dichloromethane solutions at low temperature. Blood-red and orange-red plate-like single crystals were obtained for complexes $\mathbf{1}$ and $\mathbf{2}$, respectively. The crystallographic parameters and the X-ray structures for complexes 1 and 2 are shown in Table S1 (see SI) and Figure 3 , respectively. The lattice and structural parameters are similar to those reported in the literature ${ }^{48}$ but free from any disorder of the $\mathrm{N} 1$ and $\mathrm{C} 7$ atoms in 2 . The expected distorted square pyramidal geometry is found for $\mathbf{1}$ and $\mathbf{2}$ around the iron (I) centers. ${ }^{35,49}$ The $\mathrm{P}\left(4-\mathrm{C}_{6} \mathrm{H}_{4} \mathrm{OCH}_{3}\right)_{3}$ and $\mathrm{PPh}_{2} \mathrm{Py}$ ligands occupy the apical position, which is similar to that seen for other reported monodentate phosphine-substituted complexes, such as $\left[\mathrm{Fe}_{2}(\mathrm{CO})_{5}(\mu\right.$-pdt $\left.)\left(\mathrm{PPh}_{2} \mathrm{Py}\right)\right],\left[\mathrm{Fe}_{2}(\mathrm{CO})_{5}(\mu\right.$-Mebdt $)$ $\left.\left(\mathrm{PPh}_{3}\right)\right], \quad\left[\mathrm{Fe}_{2}(\mathrm{CO})_{5}(\mu\right.$-bdt $\left.)\left(\mathrm{PPh}_{3}\right)\right], \quad\left[\mathrm{Fe}_{2}(\mathrm{CO})_{4}(\mu\right.$-bdt $)-$ $\left.\left(\mathrm{PPh}_{3}\right)_{2}\right], \quad\left[\mathrm{Fe}_{2}(\mathrm{CO})_{5}(\mu\right.$-bdt $\left.)\left(\mathrm{PPh}_{2} \mathrm{Me}\right)\right]$, and $\left[\mathrm{Fe}_{2}(\mathrm{CO})_{4}(\mu\right.$ bdt $\left.\left(\mathrm{PPh}_{2} \mathrm{Me}\right)_{2}\right]^{32,45,49} \mathrm{~A}$ full list of bond lengths and bond angles for complexes $\mathbf{1}$ and $\mathbf{2}$ is given in Table S2 (see SI). The
Fe-Fe distances in 1 and 2 are 2.4901(9) and 2.4769(9) A, respectively, which are close to that reported for the $[\mathrm{FeFe}]$ hydrogenase enzyme active site $(2.6 \AA){ }^{4}$

The $\mathrm{Fe}-\mathrm{Fe}$ bond distance for $\mathbf{1}$ is, however, slightly elongated compared to that of 2 because of the stronger $\sigma$ donor properties of $\mathrm{P}\left(4-\mathrm{C}_{6} \mathrm{H}_{4} \mathrm{OCH}_{3}\right)_{3}$ ligand in comparison to the $\mathrm{PPh}_{2} \mathrm{Py}$ ligand. The methoxy groups in the para-position of the phenyl rings make the phosphorus atom more electrondonating. Moreover, the $\mathrm{Fe}-\mathrm{Fe}$ bond distance in $\mathbf{1}$ and $\mathbf{2}$ is greater than the all carbonyl $\left[\mathrm{Fe}_{2}(\mathrm{CO})_{6}(\mu\right.$-Mebdt $\left.)\right]$ complex $(2.4754 \AA)^{49}$ but similar to that reported in related compounds containing apical monodentate phosphine ligands. ${ }^{45}$ Characteristic structural parameters for $\mathbf{1}$ and $\mathbf{2}$ from calculations are compared with those from the X-ray structural analyses in Table 1. The agreement between experimental and calculated structural parameters is within $\sim 0.05 \AA$ for bond distances and $4^{\circ}$ for bond angles.

Spectroscopic Characterization. The spectroscopic data (FTIR and NMR) for complexes 1 and 2 match well with those reported for similar complexes (Figures S1-S5, see SI). ${ }^{48}$ The FTIR spectra of the mono-substituted complexes 1 and 2 show strong absorption bands in the regions 2042-1916 and $2046-1934 \mathrm{~cm}^{-1}$ in acetonitrile and dichloromethane, respectively, that are assigned to vibrations of terminal carbonyl groups (Table S3, see SI).

The calculated IR spectra of complexes $\mathbf{1}$ and $\mathbf{2}$ are in good agreement with the experiment. The spectra of $\mathbf{1}$ and $\mathbf{2}$ are almost indistinguishable (Figure S5, see SI). Only after the first 

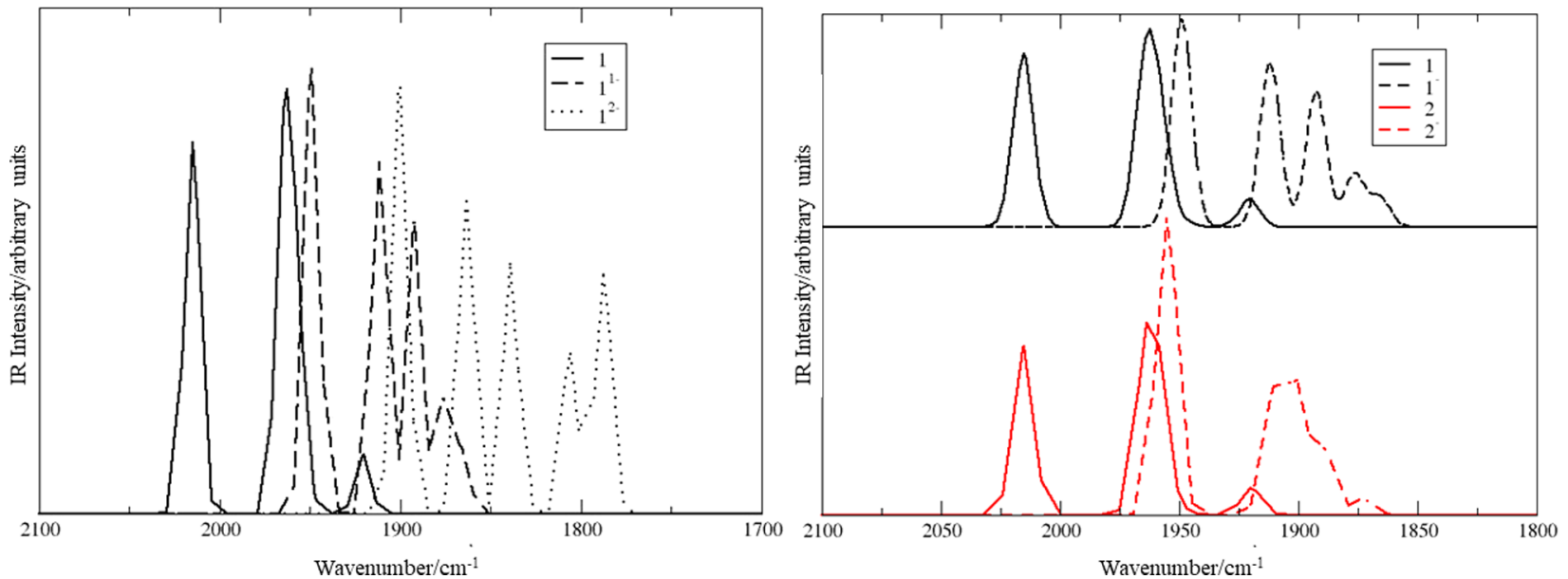

Figure 4. Computational IR spectra. Left: for complexes $1 / 1^{-} / 1^{2-}$; right: comparison of calculated spectra of $1 / 1^{-}$and $2 / 2^{-}$.

Table 2. Electrochemical Data of Complexes 1 and 2

$\begin{array}{cc}\text { complex } & E_{\mathrm{pc}} / \mathrm{V} \\ \mathbf{1} & -1.68 \\ \mathbf{2} & -1.66 \\ & -2.92\end{array}$

$\begin{array}{ll}E_{\mathrm{pa}} / \mathrm{V} & E_{\text {cat }} / \mathrm{V} \\ 0.45^{b} & -2.15^{c} \\ 0.48^{b} & -2.14^{c}\end{array}$

overpotentia
$0.69^{c}$
$0.68^{c}$

$E_{\mathrm{cat}} / \mathrm{V}$
$-1.63^{d}$
$-1.60^{d}$

overpotential
$0.76^{d}$
$0.73^{d}$

${ }^{a} E_{\mathrm{pa}}$ (anodic peak potential) for irreversible process. ${ }^{b} E_{\mathrm{pc}}$ (cathodic peak potential) for irreversible process. ${ }^{c}$ In the presence of acetic acid (AA). ${ }^{d}$ In the presence of trifluoroacetic acid (TFA).

one-electron reduction, small differences in the calculated IR spectra of $\mathbf{1}^{-} / \mathbf{2}^{-}$become apparent (Figure 4). In $\mathbf{1}^{-}$, the coordination environment of the carbonyl ligands becomes slightly unsymmetrical, while in $\mathbf{2}^{-}$, the ligand environment is still symmetric (Figure 4, right).

Electrochemistry. The redox behavior of the diiron complexes $\mathbf{1}$ and $\mathbf{2}$ was investigated in acetonitrile by cyclic voltammetry. The reduction potentials are given in Table 2, and all potentials are referenced to $\mathrm{Fc} / \mathrm{Fc}^{+}$unless otherwise noted.

Complex 1 with the $\mathrm{P}\left(4-\mathrm{C}_{6} \mathrm{H}_{4} \mathrm{OCH}_{3}\right)_{3}$ ligand displays one irreversible reduction wave at $-1.68 \mathrm{~V}$. On the other hand, complex 2 with $\mathrm{PPh}_{2} \mathrm{Py}$ moiety (with a pendant amine in the monodentate phosphine ligand) displays two irreversible reduction peaks at -1.66 and $-2.92 \mathrm{~V}$ (Figure 5). The irreversibility of the reduction peaks was also confirmed from the CVs at different scan rates (Figure S6, see SI). The oneelectron reduction was assigned based on the bulk electrolysis

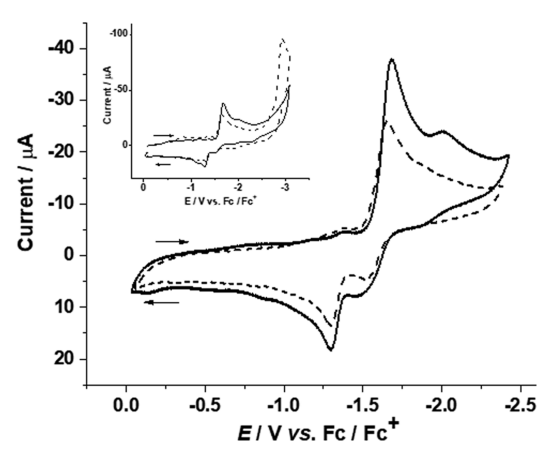

Figure 5. Cyclic voltammograms (CVs) for reduction of complexes 1 $(1.40 \mathrm{mM})(-)$ and $2(1.46 \mathrm{mM})(-$.$) in acetonitrile \left(v s \mathrm{Fc} / \mathrm{Fc}^{+}\right)$at a scan rate of $0.1 \mathrm{~V} \mathrm{~s}^{-1}$. Inset: Full-range CVs of complexes 1 (-) and $2(-)^{-}$in acetonitrile at a scan rate of $0.1 \mathrm{~V} \mathrm{~s}^{-1}$. experiments (Figure S7, see SI). The peaks for oxidation of complexes 1 and 2 appear at +0.45 and $+0.48 \mathrm{~V}$, respectively (Figure S8, see SI). The more negative potentials for $\mathbf{1}$ and $\mathbf{2}$ in comparison to $\left[\mathrm{Fe}_{2}(\mathrm{CO})_{6}(\mu\right.$-Mebdt $\left.)\right]$ are due to substitution of $\mathrm{CO}$ with phosphine ligands. ${ }^{49}$ An additional reduction wave was also observed at -2.02 and $-1.90 \mathrm{~V}$ for 1 and 2 , respectively. The appearance of reduction peaks for complex $\mathbf{1}$ at a more negative potential than $\mathbf{2}$ is in agreement with FTIR and NMR data and shows that the $\mathrm{P}(4-$ $\left.\mathrm{C}_{6} \mathrm{H}_{4} \mathrm{OCH}_{3}\right)_{3}$ ligand is slightly more electron-donating than $\mathrm{PPh}_{2} \mathrm{Py}$. The observation of anodic peaks between -1.29 and $-1.31 \mathrm{~V}$ for 1 and 2 suggests slow exchange of a CO ligand for a weakly bound solvent molecule after reduction. A similar ligand exchange has been previously reported for $[2 \mathrm{Fe} 2 \mathrm{~S}]$ complexes containing monodentate phosphine ligands. ${ }^{50-52}$

The calculated structures of the mono-reduced species $\mathbf{1}^{-}$ and $2^{-}$are given in Figure 6 together with the calculated unpaired spin density distribution. For complex 2, the unpaired spin density is evenly distributed between the metal ions with spin densities of 0.31 and 0.28 and changes in structural parameters are only minor (Table 1 ). In $\mathbf{1}^{-}$, however, one of the distal $\mathrm{Fe}-\mathrm{S}$ bonds is broken and the distance increases from $2.31 \AA$ in $\mathbf{1}$ to $2.76 \AA$ in $\mathbf{1}^{-}$which opens up accessible site for protonation (Table 1). Here, the reduction is occurring at the distal iron atom. The unpaired spin density is 0.74 at the distal iron and close to zero at the proximal iron. The bridging sulfur atom has an unpaired spin of 0.11 . The calculated changes in Gibbs free energies for the first reduction step of $\mathbf{1}$ / $1^{-}(-72 \mathrm{kcal} / \mathrm{mol}$ for BP86; $-70 \mathrm{kcal} / \mathrm{mol}$ with B3LYP $)$ and $2 / 2^{-}$(-69 kcal/mol for BP86; $-70 \mathrm{kcal} / \mathrm{mol}$ with B3LYP) are almost indistinguishable and again confirm the very similar electronic properties of the compounds. The calculated redox potential of $-1.62 \mathrm{~V}$ agrees well with the experimental value.

The electrocatalytic properties of complexes 1 and 2 were investigated in the presence of acids of varying strengths. Upon 
A
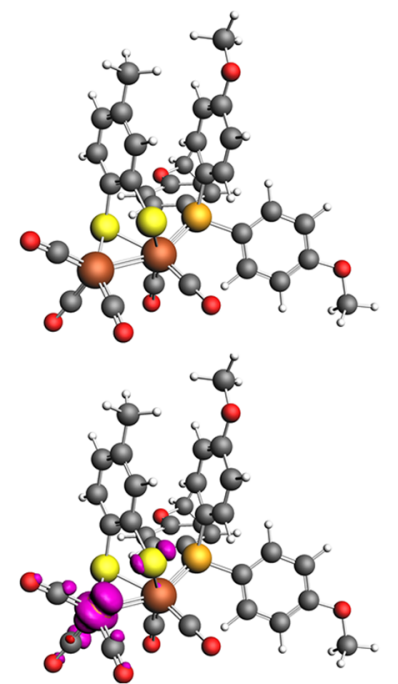

B
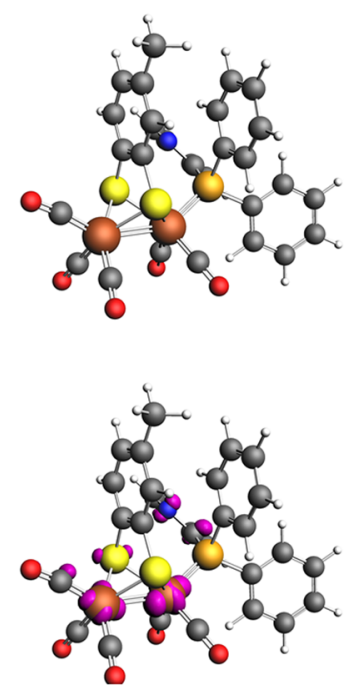

Figure 6. Structures and unpaired spin density distributions at 0.005 au of mono-reduced $\mathrm{Fe}^{0} \mathrm{Fe}^{\mathrm{I}}$ species: (A) $\mathbf{1}^{-}$and (B) $\mathbf{2}^{-}$.
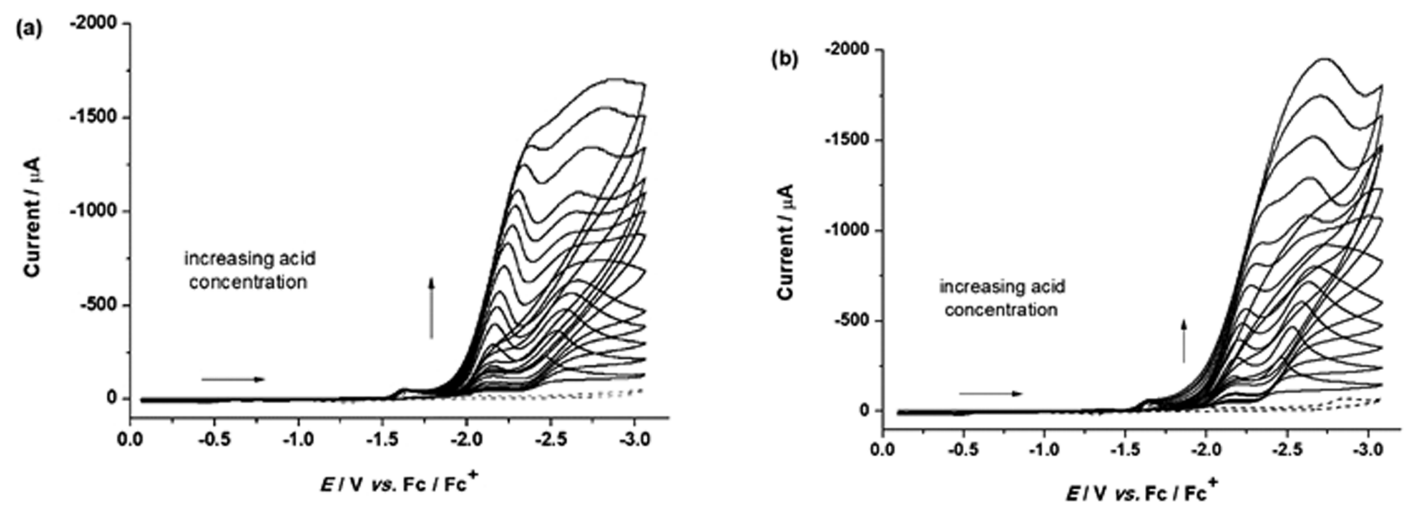

Figure 7. Cyclic voltammograms of (a) complex $1(1.1 \mathrm{mM})$ and (b) complex $2(1.1 \mathrm{mM})$ in acetonitrile without acid (- - -) and with increasing amounts $(6-197 \mathrm{mM})$ of acid $(-)\left(\mathrm{CH}_{3} \mathrm{COOH}\right)$ at a scan rate of $0.1 \mathrm{~V} \mathrm{~s}^{-1}$.
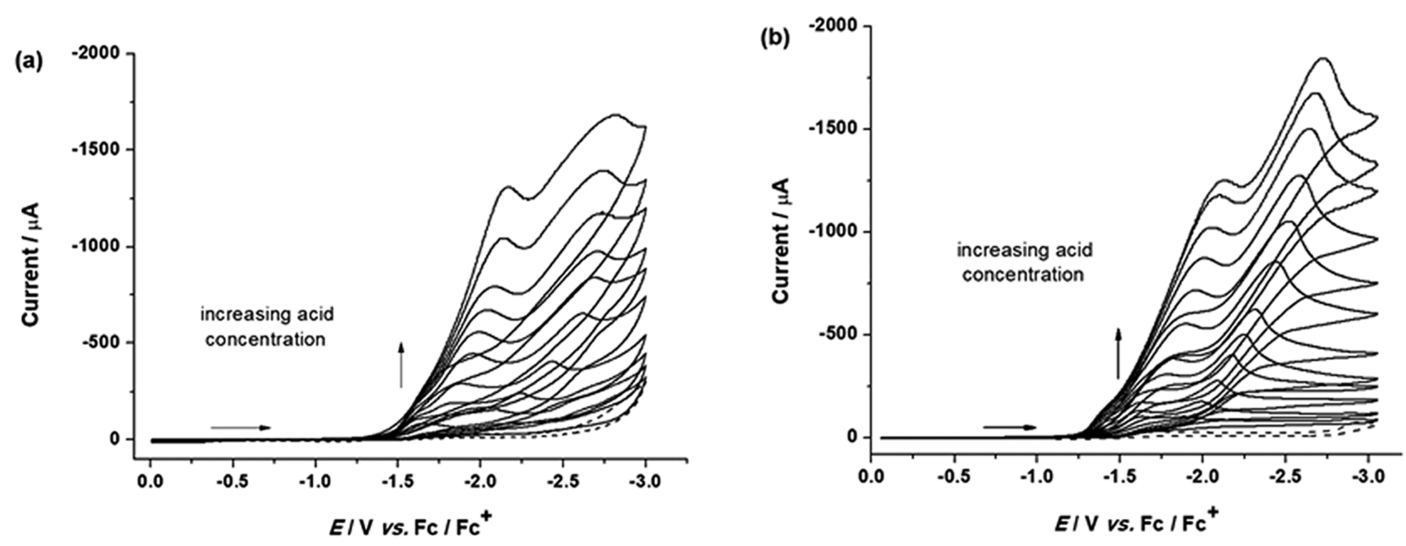

Figure 8. Cyclic voltammograms of (a) complex $\mathbf{1}(1.1 \mathrm{mM})$ and (b) complex $2(1.1 \mathrm{mM})$ in acetonitrile without acid (- - -) and with increasing amounts $(1-55 \mathrm{mM}$ for 1 and $1-78 \mathrm{mM}$ for 2$)$ of acid $(-)\left(\mathrm{CF}_{3} \mathrm{COOH}\right)$ at a scan rate of $0.1 \mathrm{~V} \mathrm{~s}^{-1}$.

addition of acetic acid (AA), new reduction peaks (cathodically shifted) were observed at potentials of -2.15 and $-2.14 \mathrm{~V}$ for 1 and 2, respectively. The current height for these new reduction peaks increased with acid concentration initially and leveled off after addition of $\sim 200 \mathrm{mM}$ acid (Figure 7).

However, the peak currents for the initial reduction peaks of $\mathbf{1}$ and $\mathbf{2}$ increase only slightly on addition of acetic acid. The cyclic voltammograms also displayed cathodically shifted second reduction peaks at $-2.47 \mathrm{~V}$ for 1 and $-2.44 \mathrm{~V}$ for 2 in the presence of increasing amounts of AA. Acetic acid reduction was observed at $-2.56 \mathrm{~V} v s \mathrm{Fc} / \mathrm{Fc}^{+}$in the absence of a catalyst, while the catalytic reductions were observed at potentials less than $-2.56 \mathrm{~V}$ (Figure S9, see SI). The peak catalytic currents were comparable for both 1 and 2. The plot of current versus acid concentration (AA) for the complexes is shown in Figure S10 (see SI), wherein the current increases 
Scheme 1. Suggested Reaction Mechanisms for Acid-Assisted Proton Reduction of Complex $1^{a}$
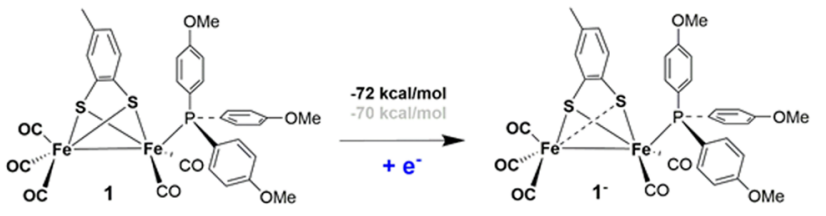

$\underset{\substack{-27 \mathrm{kcal} / \mathrm{mol} \\-26 \mathrm{kcal} / \mathrm{mol}}}{-\mathrm{H}_{2}}$
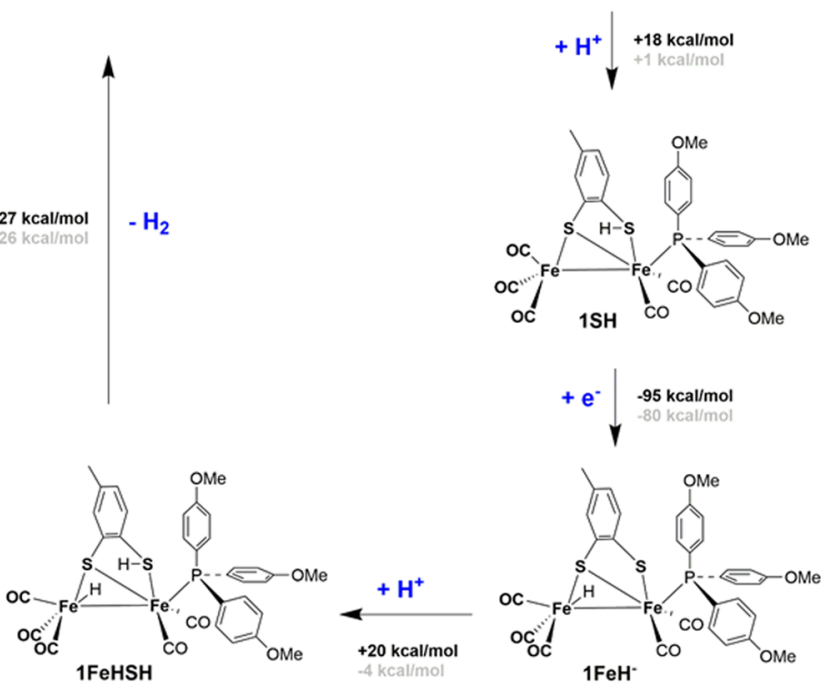

BP86D3 (acetonitrile)
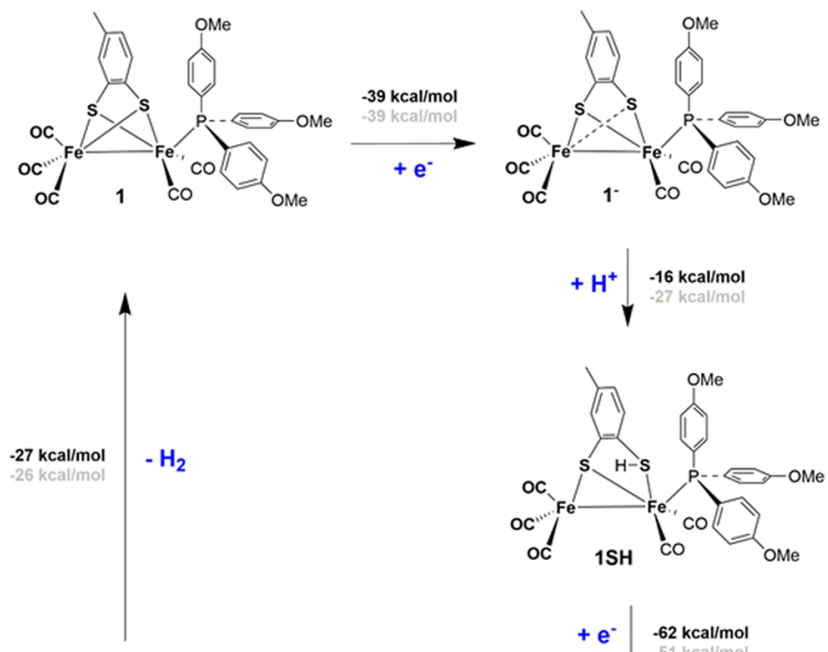

$+\mathrm{H}^{+} \downarrow \begin{aligned} & -16 \mathrm{kcal} / \mathrm{mol} \\ & -27 \mathrm{kcal} / \mathrm{mol}\end{aligned}$
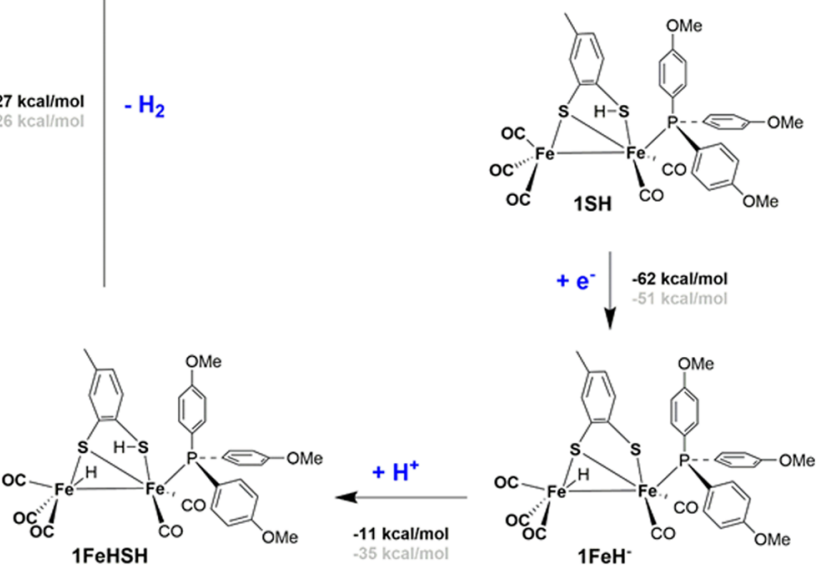

BP86D3

${ }^{a}$ Left: Gibbs free energy difference in an implicit solvent model (COSMO); Right: Gibbs free energy difference in the absence of a solvent. All values in $\mathrm{kcal} / \mathrm{mol}$.

and then levels off with a maximum of $200 \mathrm{mM}$ acid in the solution, indicating that catalysis becomes independent of acid concentration. The coulometry data also support the electrocatalytic activity of the complexes (Figure S11, see SI). There was not much difference in the overpotentials $(0.69 \mathrm{~V}$ for 1 and $0.68 \mathrm{~V}$ for 2 ) associated with the catalytic reduction of acetic acid $\left(E_{\mathrm{AcOH}}{ }^{0}=-1.46 \mathrm{~V}\right)^{53}$ by both the complexes (Table 2). Similar types of model complexes have been reported previously with large catalytic currents and overpotentials. $^{54,55}$ The first reduction potentials $1 / \mathbf{1}^{-}$and $\mathbf{2 / 2 ^ { - }}$ are not sufficient to reduce protons from acetic acid. This is indicated by the first reduction peaks of the complexes for which the current does not increase on addition of acid. However, there are examples of complexes that give a notable increase in peak current at the first reduction potential in the presence of acetic acid. ${ }^{32,55}$ Henceforth, a mechanism of electrochemical reduction $(E)$, followed by a first protonation (C) appears more plausible. The monoprotonated species $\mathbf{1} \mathbf{H}$ and $2 \mathrm{H}$ are then reduced at -2.15 and $-2.14 \mathrm{~V}$, respectively.

The electrocatalytic properties of $\mathbf{1}$ and $\mathbf{2}$ were also investigated in the presence of perchloric acid and trifluoroacetic acid (TFA). With $\mathrm{HClO}_{4}$, catalysis was observed for both the complexes (addition of up to $15 \mathrm{mM}$ of acid) with an overpotential of $\left.1 \mathrm{~V}\left(E_{\mathrm{HClO}_{4}}{ }^{0}=-0.26 \mathrm{~V}\right)\right)^{53,54}$ Since low currents were observed, detailed investigations were not carried out. The slow reaction with perchloric acid could be related to catalyst instability and loss of reactivity. With TFA, new reduction peaks were observed at -1.63 and $-1.60 \mathrm{~V}$ for 1 and 2, respectively, that shifted cathodically on further addition of acid. ${ }^{53,54} \mathrm{~A}$ second set of peaks at -2.10 and -1.93 $\mathrm{V}$ for $\mathbf{1}$ and 2, respectively, was also observed (Figure 8). The appearance of multiple peaks with TFA as a proton source could be attributed to homoconjugation of the acid. ${ }^{56,57}$ The background currents without catalyst in the presence of TFA due to direct reduction of protons at the glassy carbon electrode were found to be negligible for potentials in the range of -1.2 to $-1.9 \mathrm{~V}$ and hence, the acid-induced currents in the presence of catalysts can be attributed to catalytic turnover (Figure S12, see SI). The plot of current versus acid concentration (TFA) for the complexes is shown in Figure S13 (see SI).

Reaction Mechanism of Proton Reduction. As mentioned above, the mono-reduced state $\mathbf{1}^{-}(E)$ possesses an accessible site of protonation at one of the bridging Mebdt thiolate sulfur atoms. The Gibbs free energies for sulfur protonation of $-16 \mathrm{kcal} / \mathrm{mol}(\mathrm{BP} 86)$ and $-27 \mathrm{kcal} / \mathrm{mol}$ (B3LYP) show the feasibility for the first step of protonation (C). Only the application of implicit solvation leads to a positive Gibbs free energy change of +18 or $+1 \mathrm{kcal} / \mathrm{mol}$, respectively. This is an indication of the problem of treating charged compounds reliably in an implicit solvation model. It is this difference in solvation energies between $\mathbf{1}^{-}$and $\mathbf{1 S H}$ of $29 \mathrm{kcal} / \mathrm{mol}$ that renders the calculated protonation energies in a solvent to become positive. Upon the second one-electron reduction, a spontaneous intramolecular proton transfer from $\mathbf{1 S H}$ to the distal iron atom to give $\mathbf{1} \mathbf{F e H}{ }^{-}$occurs $(-95 \mathrm{kcal} /$ mol with BP86 and $-80 \mathrm{kcal} / \mathrm{mol}$ with B3LYP). This recovers the site of protonating at the Mebdt thiolate. The second step of protonation (ECEC) to give 1FeHSH again is clearly possible with calculated protonation Gibbs free energies of $-11 \mathrm{kcal} / \mathrm{mol}$ (BP86) and $-35 \mathrm{kcal} / \mathrm{mol}$ (B3LYP). Again, the large difference in solvation energies between $\mathbf{1 F e H}^{-}$and 
Scheme 2. ECEC Mechanism for Acid-Assisted Proton Reduction of Complex 2

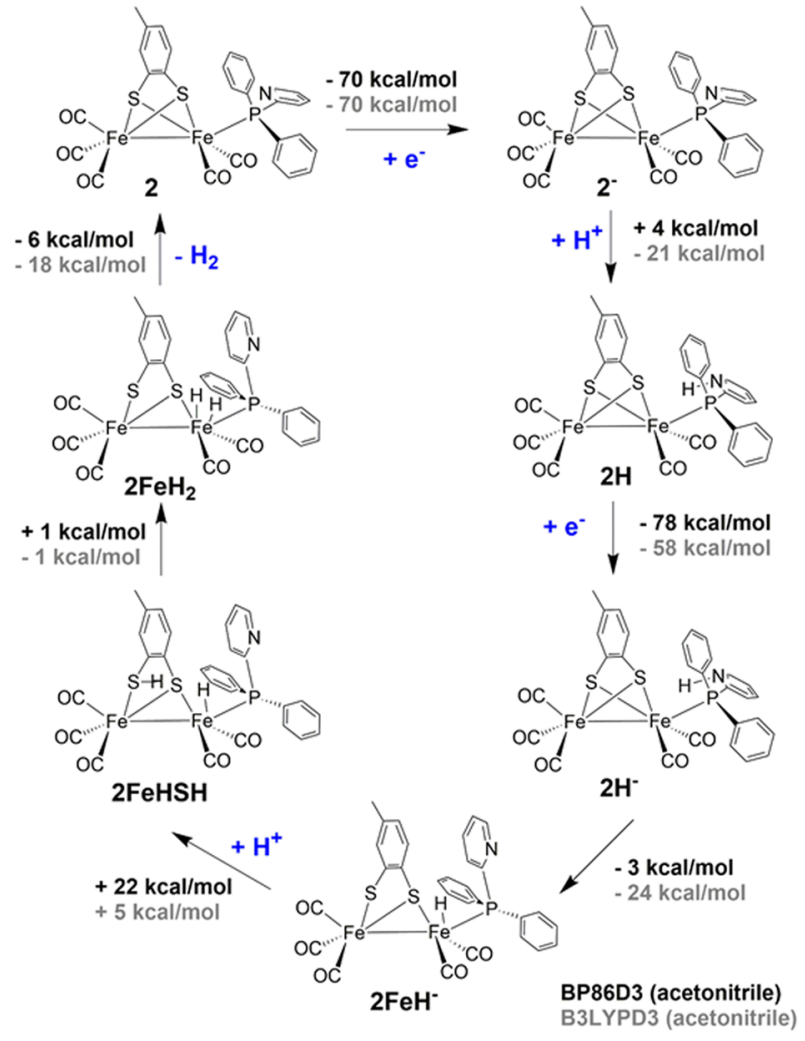

1FeHSH of $31 \mathrm{kcal} / \mathrm{mol}$ gives positive Gibbs free energies for protonation in solvent. The release of molecular hydrogen from 1FeHSH is thermodynamically driven by -27 and -26 $\mathrm{kcal} / \mathrm{mol}$ and recovers complex $\mathbf{1}$ (Scheme 1).

Interestingly, the HER is centered at the distal iron atom only: protonation and one-electron reduction steps involve one of the bridging thiolates and the distal iron only (Scheme 1). The proximal iron atom is stabilized by $\pi-\pi$ stacking interaction with one of the terminal $4-\mathrm{C}_{6} \mathrm{H}_{4} \mathrm{OCH}_{3}$ groups. This interaction is persistent throughout the entire catalytic cycle and obstructs large structural rearrangements of the iron atoms and the bridging $\mu$-Mebdt ligand (Figure S14, see SI). Actually, during the HER of $\mathbf{1}$, the $\mathrm{Fe}-\mathrm{Fe}$ bond distance only changes from $2.55 \AA$ in 1 to $2.73 \AA$ in $\mathbf{1 F e H S H}$. Likewise, the center-to-center distance between the bridging aromatic Mebdt ligand and aromatic rings of tris(4-methoxyphenyl)phosphine ligand varies between $3.43 \AA$ in $\mathbf{1} \mathbf{F e H}^{-}$(strong stabilizing effect, one $\mathrm{Fe}-\mathrm{S}$ bond broken, iron atom protonated) and $3.74 \AA$ in $\mathbf{1 F e H S H}$ (weak stabilization enabling release of $\mathrm{H}_{2}$ ) (Figure $\mathrm{S} 14$, see SI). A similar stabilizing effect by a bridging aromatic thiolate and a terminal aromatic ring of the phosphine substituent was also observed in an earlier report by our group. ${ }^{46}$ An EECC mechanism with two consecutive one-electron steps to give $\mathbf{1}^{2-}$ (with Gibbs free energy changes of $-140 \mathrm{kcal} / \mathrm{mol}$ for BP86 and $-123 \mathrm{kcal} /$ mol for B3LYP) and two sequential steps of protonation also appears feasible since protonation will be facile and swift then (Scheme S2, see SI). This is also evident from the reduction peaks at -2.47 and $-2.44 \mathrm{~V}$, which can be associated with the reduction of $1^{-} / 2^{-}$to $1^{2-} / 2^{2-}$. However, when the acetic acid concentration is increased, the hydride-containing species $1 \mathrm{H} /$ $2 \mathrm{H}$ are generated and are then reduced at -2.15 and -2.14 $\mathrm{V}^{23}$ Both mechanisms may operate in parallel and be
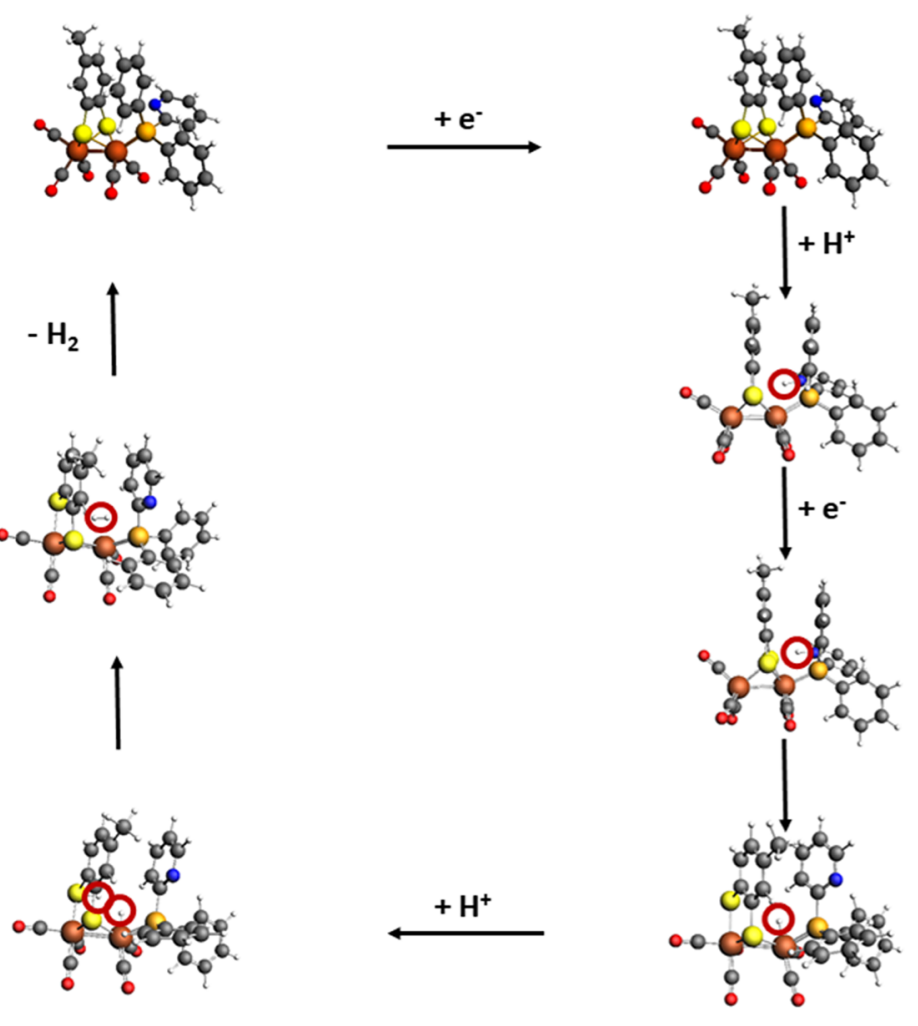

controlled by the $\mathrm{p} K_{\mathrm{a}}$ of the acid $v s$ closely spaced redox potential. $^{58}$

The overall mechanistic picture of HER of complex 2 appears to be similar to that of $\mathbf{1}$ at first glance only (Scheme $2)$. The first one-electron reduction to afford $2^{-}$occurs with a change in Gibbs free energies of -69 and $-70 \mathrm{kcal} / \mathrm{mol}$ for BP86 and B3LYP, respectively, and thus almost identical to the reduction $1 / \mathbf{1}^{-}$. Unlike in $\mathbf{1}^{-}$, this first electrochemical reduction step does not induce the opening of an iron-sulfur bond and the thiolate to become available as a site for protonation. Neither the $\mathrm{Fe}-\mathrm{Fe}$ bond distances $(2.53 \AA$ in 2 and $2.66 \AA$ in $2^{-}$) nor the $\mathrm{Fe}-\mathrm{S}$ bond distances $(2.30-2.32 \AA$ in 2 and $2.31-2.40 \AA$ in $2^{-}$) change significantly. Also, the center-to-center distance between the aromatic ring of the bridging Mebdt ligand and a $p$-methoxyphenyl group of $3.62 \AA$ in 2 and $3.68 \AA$ in $2^{-}$remains almost unchanged. Although the reduction in 1 is $\mathrm{Fe}_{\mathrm{d}}(0.74)$ - and thiolate (0.11)-based, in $2^{-}$, the unpaired spin is delocalized over the two iron atoms $(0.39$ at the $\mathrm{Fe}_{\mathrm{d}}$ and 0.28 at the proximal $\mathrm{Fe}_{\mathrm{p}}$ ) and, to a lesser degree, over one of the sulfur atoms $(0.05)$ and the nitrogen atom of the pyridine $(0.05)$. This demonstrates that (i) the simultaneous stability and plasticity of complex are able to easily accommodate an extra electron without large structural changes, and (ii) modulation of the terminal ligand leads to a change from reduction of only $\mathrm{Fe}_{\mathrm{d}}$ in $\mathbf{1}$ to a delocalized $\mathrm{Fe}_{\mathrm{d}} /$ $\mathrm{Fe}_{\mathrm{p}}$ reduction in 2 .

This partial reduction of the pyridine ring increases its electron richness, making the pyridine nitrogen basic enough to become protonated (to give $\mathbf{2 H}$ ) in the subsequent step. Since all other covalent bonds are intact, this is the only possible site of protonation in $\mathbf{2}^{-}$. The Gibbs energies of protonation in the gas phase of $-64(\mathrm{BP} 86)$ and $-79 \mathrm{kcal} / \mathrm{mol}$ (B3LYP) become +4 and $-8 \mathrm{kcal} / \mathrm{mol}$, respectively, when 

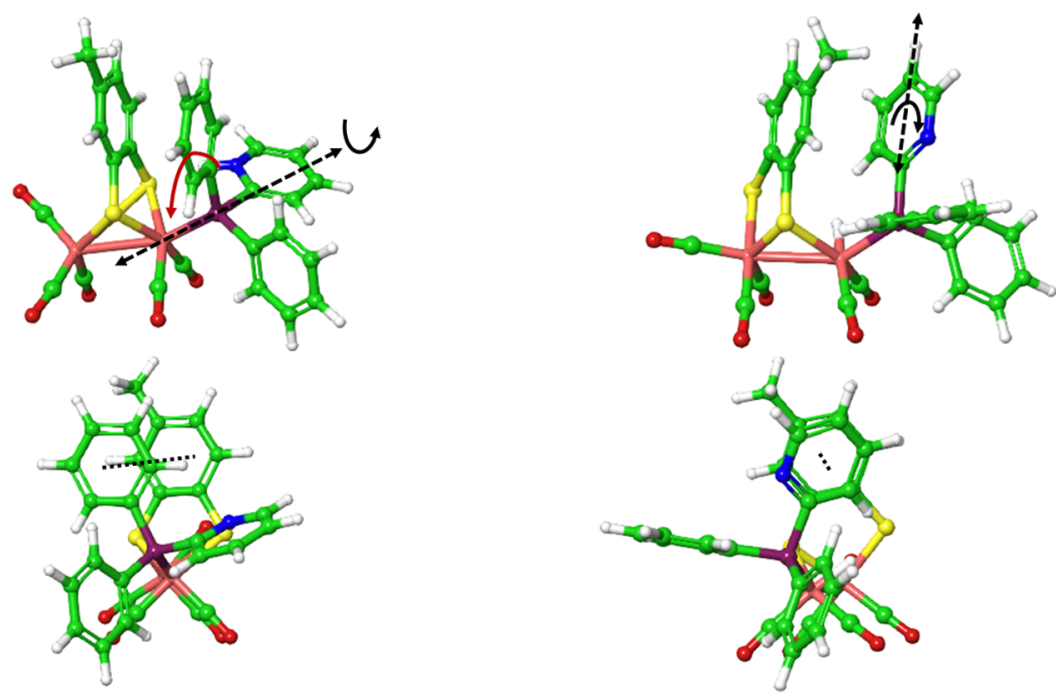

Figure 9. Intramolecular proton transfer of the pyridinium proton from $2 \mathbf{H}^{-}$(left) to the proximal iron atom $\mathrm{Fe}_{\mathrm{p}}$ to yield $2 \mathrm{FeH}^{-}$(right). This transfer is accompanied by a phosphine ligand rotation to bring the pyridine into the stacking position with Mebdt and a pyridine ring rotation around the $\mathrm{C} 2-\mathrm{C} 5$ axis.

using a COSMO model due to the difficulty with differently charged complexes.

The second one-electron reduction of $2 \mathbf{H}$ to $2 \mathbf{H}^{-}$is accompanied with a change in the Gibbs free energy of -78 and $-58 \mathrm{kcal} / \mathrm{mol}$ for BP86 and B3LYP, respectively. Large structural changes are not observed during this step. Minor changes in iron-iron bond distances by $0.3 \AA$ and Mebdtterminal ligand distance by $0.14 \AA$ rationalize the stability during the HER of complex 2 (Figure S15, see SI). A proton transfer of the pyridinium proton to the proximal iron atom is exothermic by $-6 \mathrm{kcal} / \mathrm{mol}$ for BP86 and $-24 \mathrm{kcal} / \mathrm{mol}$ with B3LYP to give the terminal hydride species $2 \mathrm{FeH}$.

In $2 \mathrm{FeH}^{-}$, a $\mathrm{Fe}-\mathrm{H}$ hydride bond of $1.54 \AA$ is formed and accompanied by a concerted rearrangement of the phosphine ligand: upon proton transfer, the phosphine ligands rotate by $104^{\circ}$ around the $\mathrm{Fe}-\mathrm{P}$ bond so that the $\pi-\pi$ stacking phenyl in 2 and $2^{-}$is replaced by the pyridine ring. In $2 \mathrm{FeH}^{-}$, now the pyridine occupies the apical position and establishes stacking interactions with the benzendithiolate (with a center-to-center distance of $3.60 \AA$ ). Simultaneously, the pyridine ring undergoes a rotation around the $C_{2}-C_{5}$ axis of the fivemembered ring such that the nitrogen atom is pointing away from the proximal iron atom (Figure 9) and no longer accessible for a second protonation step. Upon generation of an iron hydride at $\mathrm{Fe}_{\mathrm{p}}$, one of the proximal iron-thiolate bonds breaks ( $\mathrm{Fe}-\mathrm{S}$ distance of $3.92 \AA)$. This monocoordinate thiolate can then be protonated to give $2 \mathrm{FeHSH}$, a formal $\mathrm{Fe}(0) \mathrm{Fe}(0)$ species which bears an iron hydride and a thiol ligand. Here, the iron-iron distance reduces from $2.89 \AA$ in $\mathbf{2} \mathbf{F e H}^{-}$to $2.72 \AA$ in $\mathbf{2 F e H S H}$ and the Mebdt-py distance reduces from 3.60 to $3.56 \AA$ (Figure S15, see SI). A close to thermoneutral transfer of the proton from the thiol to the proximal iron atom gives the intermediate $2 \mathrm{FeHH}$, which corresponds to a weakly bound $\mu-\mathrm{H}_{2}$ complex with ironhydrogen distances of 1.77 and $1.91 \AA$ and a $\mathrm{H}-\mathrm{H}$ bond distance of $0.85 \AA$. This corresponds to an activated $\mathrm{H}_{2}$ complex $(\mathrm{H}-\mathrm{H}$ bond distance of $0.75 \AA$ ). From $2 \mathrm{FeHH}$, molecular hydrogen is easily released with a change in Gibbs free energy of -6 (for BP86) and $-18 \mathrm{kcal} / \mathrm{mol}$ for B3LYP to complete the cycle.

\section{CONCLUSIONS}

Two complexes $\mathbf{1}$ and $\mathbf{2}$ with proton-assisted hydrogen evolving catalytic activity were characterized in detail using various spectroscopic techniques and quantum chemical calculations. The complexes only differ in the terminal monodentate phosphine ligands $\mathrm{P}\left(4-\mathrm{C}_{6} \mathrm{H}_{4} \mathrm{OCH}_{3}\right)_{3}$ and $\mathrm{PPh}_{2} \mathrm{Py}$ with very similar structural (X-ray) and electronic properties $\left(\nu_{\mathrm{CO}}\right.$ values and reduction potentials). The newly synthesized complexes are catalytically active in the presence of various acids (acetic acid, trifluoroacetic acid, and perchloric acid). The catalytic reduction peaks were observed at -2.15 and $-2.14 \mathrm{~V}$ for $\mathbf{1}$ and 2, respectively, while in the absence of catalysts, the reduction for acetic acid was observed at $-2.56 \mathrm{~V}$ vs $\mathrm{Fc} / \mathrm{Fc}^{+}$.

The stabilization of a terminal $\left(4-\mathrm{C}_{6} \mathrm{H}_{4} \mathrm{OCH}_{3}\right)_{3}$ phosphine ligand by a stacking interaction with a bridging $\mu$-naphthalene2-thiolate ligand significantly reduced structural changes during the catalytic cycle, hindered the rotation of the phosphine ligand, and the reaction proceeded involving a bridging hydride and a protonated thiolate species. ${ }^{46}$ In complexes 1 and 2, the formation of such a $\mu$-hydride seems to be avoided by a stacking interaction between the bridging benzenedihiolate and a terminal aromatic ring. In the absence of a bridging hydride, the terminal hydrides may react with thiol protons and release $\mathrm{H}_{2}$ in the absence of an energy barrier.

The acidity of metal hydride and dihydrogen complexes (their $\mathrm{p} K_{\mathrm{a}}$ 's) is relevant for many processes in catalysis and biology, hydrogen storage and generation, and fuel cell electrocatalysis. ${ }^{59}$ The sequential events of electrochemical ( $E$, reduction) and chemical ( $C$, protonation) steps require a detailed balance between ligand proton affinities $\left(\mathrm{p} K_{\mathrm{a}}\right)$ and transition-metal hydricities. The fine-tuning of both is critically dependent on the charge of the conjugate base complex. Here, in complex 2 , the $\mathrm{p} K_{\mathrm{a}}$ value of a pyridinium (5.25 in water) is apparently very close to that of the proximal $\mathrm{Fe}_{\mathrm{p}}$ terminal hydride.

By incorporating a pyridine nitrogen atom into a binuclear FeFe complex, the site-selective reactivity can be shifted from the distal (in 1) to the proximal (in 2) iron atom. The intramolecular stabilization by aromatic stacking interactions 
obstructs large structural rearrangements and complex degradation. The introduction of pendant amines as an initial site of protonation, then proton relay and directing the transfer of protons in mononuclear ${ }^{60-62}$ and binuclear ${ }^{33}$ complexes has been inspired by the design of the $[\mathrm{FeFe}]$ hydrogenase enzymatic system. The growing understanding and control of proton shuffling to the development of molecular electrocatalysts for energy storage ${ }^{63}$ and hydrogen production ${ }^{64}$ is striking.

\section{EXPERIMENTAL SECTION}

General Procedure. All of the experiments were carried out in an inert atmosphere using Schlenk techniques unless otherwise specified. $\left[\mathrm{Fe}_{2}(\mathrm{CO})_{6}(\mu\right.$-Mebdt $\left.)\right]$ was prepared according to the procedure reported in literature. ${ }^{49}$ All of the starting materials and anhydrous solvents were obtained from Sigma-Aldrich and used without any further purification. The deuterated solvents were also obtained from Sigma-Aldrich. The ${ }^{1} \mathrm{H}$ and ${ }^{31} \mathrm{P}$ NMR spectra were recorded at room temperature in $\mathrm{CDCl}_{3}$ with a JEOL $400 \mathrm{MHz}$ NMR spectrometer. The FTIR spectra were recorded from dichloromethane and acetonitrile solutions of the samples over the range of $400-4000 \mathrm{~cm}^{-1}$ on a PerkinElmer FTIR spectrometer. The UV-vis spectra for the complexes 1 and $\mathbf{2}$ were recorded on a PerkinElmer Lambda-25 spectrophotometer. The elemental analyses were carried out with a Vario Micro Cube elemental analyzer.

Electrochemistry. Electrochemical measurements were conducted in acetonitrile with $0.1 \mathrm{M}$ tetrabutylammoniumhexafluorophosphate (Fluka, electrochemical grade) as a supporting electrolyte that was dried in vacuum at $383 \mathrm{~K}$. Cyclic voltammetry was carried out using an Autolab potentiostat with a GPES electrochemical interface (Eco Chemie). The working electrode was a glassy carbon disk (diameter, $3 \mathrm{~mm}$; freshly polished) for cyclic voltammetry. A platinum wire was used as the counter electrode. The reference electrode was a non-aqueous $\mathrm{Ag} / \mathrm{Ag}^{+}$electrode $(\mathrm{CH}$ Instruments, $0.010 \mathrm{M}$ $\mathrm{AgNO}_{3}$ in acetonitrile). All of the potentials (text, tables, and figures) are quoted against the ferrocene-ferrocenium couple $\left(\mathrm{Fc} / \mathrm{Fc}^{+}\right)$; ferrocene was added as an internal standard at the end of the experiments. All solutions were prepared from dry acetonitrile (Sigma-Aldrich, spectroscopic grade, dried with MS $3 \AA$ Å). Controlled potential coulometry (CPC) was performed on the same instrument with the three-electrode setup described earlier. The experiment was carried out with continuous stirring and purging of argon gas at a fixed potential.

X-ray Crystallography. Single crystals of $\mathbf{1}$ and $\mathbf{2}$ were grown by slow evaporation of hexane-dichloromethane solutions at low temperature. X-ray data of $\mathbf{1}$ and $\mathbf{2}$ were collected on Oxford X-Calibur-S and Oxford SuperNova single-crystal X-ray diffractometers using Mo-K $\alpha$ radiation, respectively. Significant crystallographic parameters and refinement details are given in Tables S1 and S2 (see SI). The structures were solved and refined by full-matrix least-squares techniques on $F^{2}$ using the SHELX-97 (SHELXTL program package). ${ }^{65}$

Computational Details. ADF2018.105 ${ }^{66,67}$ was used with the BP86 ${ }^{6,69}$ and B3LYP ${ }^{70,71}$ exchange-correlation functionals, Grimme's dispersion correction with Becke-Johnson damping, $^{72}$ and a TZP Slater-type basis set for all atoms. ${ }^{73}$ The solvent (acetonitrile) was considered in a COSMO solvation model $^{74,75}$ using the Klamt atomic radii and surface definition with corrections for outlying charges. Thermodynamic corrections were obtained using statistical thermodynamics from BP86 calculations under standard conditions. ${ }^{76}$ Redox potentials were calculated following refs 44,77 and are given relative to an $\mathrm{Fc} / \mathrm{Fc}^{+}$reference electrode in acetonitrile.

\section{ASSOCIATED CONTENT}

\section{Supporting Information}

The Supporting Information is available free of charge at https://pubs.acs.org/doi/10.1021/acsomega.0c04901.

\section{Crystallographic data (CIF)}

Crystallographic data (CIF)

Details of synthesis of complexes 1 and 2 (Scheme S1); crystallographic data (Table S1); selected bond distances and angles from X-ray structural analysis (Table S2); NMR spectra of 1 (Figures S1, S2) and 2 (Figures S3, S4); FTIR spectra (Figure S5, Table S3); $\mathrm{CVs}$ of reduction at different scan rates (Figure S6); plots of charge $v s$ time for first reduction of complexes (Figure S7); CVs for oxidation of complexes (Figure S8); CVs of complexes in presence of acetic acid (Figure S9) and TFA (Figure S12); plots of current vs acid concentration (Figures S11 and S13); intramolecular stabilization of complexes during HER (Figures S14 and S15); alternative EECC mechanism for the HER of complex 1 (Scheme S2) (PDF)

\section{Accession Codes}

CCDC 2019324 and 2045900 contain the supplementary crystallographic data for this paper. These data can be obtained free of charge via www.ccdc.cam.ac.uk/data request/cif, or by emailing data_request@ccdc.cam.ac.uk, or by contacting The Cambridge Crystallographic Data Centre, 12 Union Road, Cambridge CB2 1EZ, U.K.; fax: +441223 336033.

\section{AUTHOR INFORMATION}

\section{Corresponding Authors}

Matthias Stein - Max Planck Institute for Dynamics of Complex Technical Systems, 39106 Magdeburg, Germany; (1) orcid.org/0000-0001-7793-0052;

Email: matthias.stein@mpi-magdeburg.mpg.de

Sandeep Kaur-Ghumaan - Department of Chemistry, University of Delhi, Delhi 110007, India; Max Planck Institute for Dynamics of Complex Technical Systems, 39106 Magdeburg, Germany; 이이.org/0000-0002-0688-3428; Email: skaur@chemistry.du.ac.in

\section{Authors}

Indresh Kumar Pandey - Department of Chemistry, University of Delhi, Delhi 110007, India

Tashika Agarwal - Department of Chemistry, University of Delhi, Delhi 110007, India

Shaikh M. Mobin - Discipline of Chemistry, Indian Institute of Technology Indore, Indore 453552, India; 이이이.org/ 0000-0003-1940-3822

Complete contact information is available at: https://pubs.acs.org/10.1021/acsomega.0c04901

\section{Author Contributions}

The manuscript was written through contributions of all authors. All authors have given approval to the final version of the manuscript. 


\section{Funding}

Funded by the Deutsche Forschungsgemeinschaft (DFG, German Research Foundation) - TRR 63 "Integrated Chemical Processes in Liquid Multiphase Systems" (subproject A4) - 56091768. Gefördert durch die Deutsche Forschungsgemeinschaft (DFG)-TRR 63 "Integrierte chemische Prozesse in flüssigen Mehrphasensystemen" (Teilprojekt A4)56091768

\section{Notes}

The authors declare no competing financial interest.

\section{ACKNOWLEDGMENTS}

Financial support from the Council of Scientific \& Industrial Research (CSIR), New, Delhi, India (01(2957)/18/EMR-II), and the Max Planck Society for the Advancement of Science is gratefully acknowledged. S.K.-G. is thankful to the University of Delhi, India, for providing R\&D grant and to DST and Max Planck Society for the Max Planck-India Visiting Fellowship. I.K.P. and T.A. are grateful to UGC for Research Fellowship.

\section{DEDICATION}

Dedicated to Professor Wolfgang Kaim on the occasion of his 70th birthday.

\section{REFERENCES}

(1) Vignais, P. M.; Billoud, B. Occurrence, Classification, and Biological Function of Hydrogenases: An Overview. Chem. Rev. 2007, 107, 4206-4272.

(2) Lubitz, W.; Ogata, H.; Rüdiger, O.; Reijerse, E. Hydrogenases. Chem. Rev. 2014, 114, 4081-4148.

(3) Nicolet, Y.; Piras, C.; Legrand, P.; Hatchikian, C. E.; FontecillaCamps, J. C. Desulfovibrio Desulfuricans Iron Hydrogenase: The Structure Shows Unusual Coordination to an Active Site Fe Binuclear Center. Structure 1999, 7, 13-23.

(4) Peters, J. W.; Lanzilotta, W. N.; Lemon, B. J.; Seefeldt, L. C. XRay Crystal Structure of the Fe-Only Hydrogenase (CpI) from Clostridium pasteurianum to 1.8 Angstrom Resolution. Science 1998, 282, 1853-1858.

(5) Silakov, A.; Wenk, B.; Reijerse, E.; Lubitz, W. ${ }^{14} \mathrm{~N}$ HYSCORE Investigation of the $\mathrm{H}$-Cluster of [FeFe] Hydrogenase: Evidence for a Nitrogen in the Dithiol Bridge. Phys. Chem. Chem. Phys. 2009, 11, 6592-6599.

(6) Erdem, Ö. F.; Schwartz, L.; Stein, M.; Silakov, A.; KaurGhumaan, S.; Huang, P.; Ott, S.; Reijerse, E. J.; Lubitz, W. A Model of the $[\mathrm{FeFe}]$ Hydrogenase Active Site with a Biologically Relevant Azadithiolate Bridge: A Spectroscopic and Theoretical Investigation. Angew. Chem., Int. Ed. 2011, 50, 1439-1443.

(7) Erdem, Ö. F.; Stein, M.; Kaur-Ghumaan, S.; Reijerse, E. J.; Ott, S.; Lubitz, W. Effect of Cyanide Ligands on the Electronic Structure of $[\mathrm{FeFe}]$ Hydrogenase Active-Site Model Complexes with an Azadithiolate Cofactor. Chem. - Eur. J. 2013, 19, 14566-14572.

(8) Belkova, N. V.; Shubina, E. S.; Epstein, L. M. Diverse World of Unconventional Hydrogen Bonds. Acc. Chem. Res. 2005, 38, 624631.

(9) Nicolet, Y.; Lacey, A. L.; De; Vernède, X.; Fernandez, V. M.; Hatchikian, E. C.; Fontecilla-Camps, J. C. Crystallographic and FTIR Spectroscopic Evidence of Changes in $\mathrm{Fe}$ Coordination Upon Reduction of the Active Site of the Fe-Only Hydrogenase from Desulfovibrio desulfuricans. J. Am. Chem. Soc. 2001, 123, 1596-1601.

(10) Artz, J. H.; Zadvornyy, O. A.; Mulder, D. W.; Keable, S. M.; Cohen, A. E.; Ratzloff, M. W.; Williams, S. G.; Ginovska, B.; Kumar, N.; Song, J.; et al. Tuning Catalytic Bias of Hydrogen Gas Producing Hydrogenases. J. Am. Chem. Soc. 2020, 142, 1227-1235.

(11) Siegbahn, P. E. M.; Tye, J. W.; Hall, M. B. Computational Studies of [NiFe] and [FeFe] Hydrogenases. Chem. Rev. 2007, 107, 4414-4435.
(12) Blomberg, M. R. A.; Borowski, T.; Himo, F.; Liao, R. Z.; Siegbahn, P. E. M. Quantum Chemical Studies of Mechanisms for Metalloenzymes. Chem. Rev. 2014, 114, 3601-3658.

(13) Qiu, S.; Li, Q.; Xu, Y.; Shen, S.; Sun, C. Learning from Nature: Understanding Hydrogenase Enzyme Using Computational Approach. Wiley Interdiscip. Rev.: Comput. Mol. Sci. 2020, 10, No. e1422.

(14) Tard, C.; Pickett, C. J. Structural and Functional Analogues of the Active Sites of the [Fe]-, [NiFe]-, and [FeFe]-Hydrogenases. Chem. Rev. 2009, 109, 2245-2274.

(15) Gloaguen, F.; Rauchfuss, T. B. Small Molecule Mimics of Hydrogenases: Hydrides and Redox. Chem. Soc. Rev. 2009, 38, 100108.

(16) Schilter, D.; Camara, J. M.; Huynh, M. T.; Hammes-Schiffer, S.; Rauchfuss, T. B. Hydrogenase Enzymes and Their Synthetic Models: The Role of Metal Hydrides. Chem. Rev. 2016, 116, 8693-8749.

(17) Rauchfuss, T. B. Diiron Azadithiolates as Models for the $[\mathrm{FeFe}]$-Hydrogenase Active Site and Paradigm for the Role of the Second Coordination Sphere. Acc. Chem. Res. 2015, 48, 2107-2116.

(18) Wang, N.; Wang, M.; Zhang, T.; Li, P.; Sun, L. A ProtonHydride Diiron Complex with a Base-containing Diphosphine Ligand Relevant to the $[\mathrm{FeFe}]-H y d r o g e n a s e$ Active Site. Chem. Commun. 2008, 5800-5802.

(19) Wang, Y.; Ahlquist, M. S. G. Mechanistic Studies on Proton Transfer in a $[\mathrm{FeFe}]$ Hydrogenase Mimic Complex. Dalton Trans. 2013, 42, 7816-7822.

(20) Ghosh, S.; Hogarth, G.; Hollingsworth, N.; Holt, K. B.; Richards, I.; Richmond, M. G.; Sanchez, B. E.; Unwin, D. Models of the Iron-Only Hydrogenase: A Comparison of Chelate and Bridge Isomers of $\mathrm{Fe}_{2}(\mathrm{CO})_{4}\left\{\mathrm{Ph}_{2} \mathrm{PN}(\mathrm{R}) \mathrm{PPh}_{2}\right\}(\mu$-Pdt) as Proton-Reduction Catalysts. Dalton Trans. 2013, 42, 6775-6792.

(21) Cui, H. H.; Wu, N. N.; Wang, J. Y.; Hu, M. Q.; Wen, H. M.; Chen, C. N. Pyridyl- and Pyrimidyl-Phosphine-Substituted [FeFe]Hydrogenase Mimics: Synthesis, Characterization and Properties. J. Organomet. Chem. 2014, 767, 46-53.

(22) Cheng, M.; Wang, M.; Zheng, D.; Sun, L. Effect of the S-to-S Bridge on the Redox Properties and $\mathrm{H}_{2}$ Activation Performance of Diiron Complexes Related to the $[\mathrm{FeFe}]$-Hydrogenase Active Site. Dalton Trans. 2016, 45, 17687-17696.

(23) Li, Y. L.; Ma, Z. Y.; He, J.; Hu, M. Y.; Zhao, P. H. Aminophosphine-Substituted Diiron Dithiolate Complexes: Synthesis, Crystal Structure, and Electrocatalytic Investigation. J. Organomet. Chem. 2017, 851, 14-21.

(24) Zhao, P. H.; Ma, Z. Y.; Hu, M. Y.; Jing, X.; Bin; Wang, Y. H.; Liu, X. F. The Effect of a Pendant Amine in Phosphine Ligand on the Structure and Electrochemical Property of Diiron Dithiolate Complexes. J. Coord. Chem. 2018, 71, 2941-2952.

(25) Zhao, P. H.; Ma, Z. Y.; Hu, M. Y.; He, J.; Wang, Y. Z.; Jing, X. B.; Chen, H. Y.; Wang, Z.; Li, Y. L. PNP-Chelated and -Bridged Diiron Dithiolate Complexes $\mathrm{Fe}_{2}(\mu$-Pdt $)(\mathrm{CO})_{4}\left\{\left(\mathrm{Ph}_{2} \mathrm{P}\right)_{2} \mathrm{NR}\right\}$ Together with Related Monophosphine Complexes for the $[2 \mathrm{Fe}]_{\mathrm{H}}$ Subsite of $[\mathrm{FeFe}]-$ Hydrogenases: Preparation, Structure, and Electrocatalysis. Organometallics 2018, 37, 1280-1290.

(26) Zhao, P. H.; Hu, M. Y.; Li, J. R.; Ma, Z. Y.; Wang, Y. Z.; He, J.; Li, Y. L.; Liu, X. F. Influence of Dithiolate Bridges on the Structures and Electrocatalytic Performance of Small Bite-Angle PNP-Chelated Diiron Complexes $\mathrm{Fe}_{2}(\mu$-Xdt $)(\mathrm{CO})_{4}\left\{\kappa^{2}-\left(\mathrm{Ph}_{2} \mathrm{P}\right)_{2} \mathrm{NR}\right\}$ Related to [FeFe]- Hydrogenases. Organometallics 2019, 38, 385-394.

(27) Hu, M. Y.; Li, J. R.; Jing, X.; Bin; Tian, H.; Zhao, P. H. Influence of Pendant Amines in Phosphine Ligands on the Formation, Structures, and Electrochemical Properties of Diiron Aminophosphine Complexes Related to [FeFe]-Hydrogenases. Inorg. Chim. Acta 2019, 495, No. 119021.

(28) Li, J. R.; Hu, M. Y.; Zhao, P. H.; Tian, W. J.; Xu, T. T.; Li, Y. L. Asymmetrically PNP-Chelate Diiron Ethanedithiolate Complexes $\mathrm{Fe}_{2}(\mu$-Edt $)(\mathrm{CO})_{4}\left\{\kappa^{2}-\left(\mathrm{Ph}_{2} \mathrm{P}\right)_{2} \mathrm{NR}\right\}$ as Diiron Subsite Models of [FeFe]-Hydrogenases: Structural and Electrocatalytic Investigation. Inorg. Chim. Acta 2020, 505, No. 119493.

(29) Kluwer, A. M.; Kapre, R.; Hartl, F.; Lutz, M.; Spek, A. L.; Brouwer, A. M.; van Leeuwen, P. W. N. M.; Reek, J. N. H. Self- 
Assembled Biomimetic [2Fe2S]-Hydrogenase-Based Photocatalyst for Molecular Hydrogen Evolution. Proc. Natl. Acad. Sci. U.S.A. 2009, 106, 10460-10465.

(30) Li, J. R.; Wang, Y. H.; Zhao, P. H. Crystal Structure and Electrocatalytic Investigation of Diiron Azadiphosphine Complex $\left[\mathrm{Fe}_{2}(\mu\right.$-Pdt $\left.)(\mathrm{CO})_{4}\left\{\left(\mu-\mathrm{Ph}_{2} \mathrm{P}\right)_{2} \mathrm{NH}\right\}\right]$ Related to $[\mathrm{FeFe}]$-Hydrogenases. Inorg. Nano-Metal Chem. 2020, 1-5.

(31) Zaffaroni, R.; Dzik, W. I.; Detz, R. J.; van der Vlugt, J. I.; Reek, J. N. H. Proton Relay Effects in Pyridyl-Appended Hydrogenase Mimics for Proton Reduction Catalysis. Eur. J. Inorg. Chem. 2019, 2498-2509.

(32) Li, P.; Wang, M.; Chen, L.; Liu, J.; Zhao, Z.; Sun, L. Structures, Protonation, and Electrochemical Properties of Diiron Dithiolate Complexes Containing Pyridyl-Phosphine Ligands. Dalton Trans 2009, 1919-1926.

(33) Ezzaher, S.; Capon, J. F.; Gloaguen, F.; Pétillon, F. Y.; Schollhammer, P.; Talarmin, J.; Kervarec, N. Influence of a Pendant Amine in the Second Coordination Sphere on Proton Transfer at a Dissymmetrically Disubstituted Diiron System Related to the $[2 \mathrm{Fe}]_{\mathrm{H}}$ Subsite of $[\mathrm{FeFe}] \mathrm{H}_{2}$ ase. Inorg. Chem. 2009, 48, 2-4.

(34) Wang, N.; Wang, M.; Liu, J.; Jin, K.; Chen, L.; Sun, L. Preparation, Facile Deprotonation, and Rapid H/D Exchange of the $\mu$-Hydride Diiron Model Complexes of the [FeFe]-Hydrogenase Containing a Pendant Amine in a Chelating Diphosphine Ligand. Inorg. Chem. 2009, 48, 11551-11558.

(35) Ezzaher, S.; Gogoll, A.; Bruhn, C.; Ott, S. Directing Protonation in $[\mathrm{FeFe}]$ Hydrogenase Active Site Models by Modifications in Their Second Coordination Sphere. Chem. Commun. 2010, 46, 5775-5777.

(36) Liu, X. F.; Xiao, X. W. Diiron Propanedithiolate Complex Bearing the Pyridyl-Functionalized Phosphine Ligand Axially Coordinated to a Photosensitizer Zinc Tetraphenylporphyrin. J. Organomet. Chem. 2011, 696, 2767-2771.

(37) Wang, Y.; Wang, M.; Sun, L.; Ahlquist, M. S. G. Pendant Amine Bases Speed up Proton Transfers to Metals by Splitting the Barriers. Chem. Commun. 2012, 48, 4450-4452.

(38) Lounissi, S.; Zampella, G.; Capon, J. F.; De Gioia, L.; Matoussi, F.; Mahfoudhi, S.; Pétillon, F. Y.; Schollhammer, P.; Talarmin, J. Electrochemical and Theoretical Investigations of the Role of the Appended Base on the Reduction of Protons by $\left[\mathrm{Fe}_{2}(\mathrm{CO})_{4}\left(\mathrm{~K}^{2}\right.\right.$ $\left.\mathrm{PNP}^{\mathrm{R}}\right)\left(\mathrm{M}-\mathrm{S}\left(\mathrm{CH}_{2}\right)_{3} \mathrm{~S}\right]\left(\mathrm{PNP}^{\mathrm{R}}=\left\{\mathrm{Ph}_{2} \mathrm{PCH}_{2}\right\}_{2} \mathrm{NR}, \mathrm{R}=\mathrm{Me}, \mathrm{Ph}\right)$. Chem. Eur. J. 2012, 18, 11123-11138.

(39) Becker, R.; Amirjalayer, S.; Li, P.; Woutersen, S.; Reek, J. N. H. An Iron-Iron Hydrogenase Mimic with Appended Electron Reservoir for Efficient Proton Reduction in Aqueous Media. Sci. Adv. 2016, 2, No. e1501014.

(40) Pullen, S.; Maji, S.; Stein, M.; Ott, S. Restricted Rotation of an $\mathrm{Fe}(\mathrm{CO})_{2}\left(\mathrm{PL}_{3}\right)$-Subunit in $[\mathrm{FeFe}]$-Hydrogenase Active Site Mimics by Intramolecular Ligation. Dalton Trans. 2019, 48, 5933-5939.

(41) Hu, S. P.; Zhang, L.; Wu, Y.; Feng, J. S.; Wu, S.; Xie, B.; Zou, L. K. [FeFe]-Hydrogenase Active Site Mimics Containing PyridylFunctionalized Phosphine Ligands: Synthesis, Characterization and Electrochemical Investigation. Inorg. Chim. Acta 2020, 504, No. 119435.

(42) Pandey, I. K.; Natarajan, M.; Kaur-Ghumaan, S. Hydrogen Generation: Aromatic Dithiolate-Bridged Metal Carbonyl Complexes as Hydrogenase Catalytic Site Models. J. Inorg. Biochem. 2015, 143, $88-110$.

(43) Gao, S.; Liu, Y.; Shao, Y.; Jiang, D.; Duan, Q. Iron Carbonyl Compounds with Aromatic Dithiolate Bridges as Organometallic Mimics of $[\mathrm{FeFe}]$ Hydrogenases. Coord. Chem. Rev. 2020, 402, No. 213081 .

(44) Natarajan, M.; Faujdar, H.; Mobin, S. M.; Stein, M.; KaurGhumaan, S. A Mononuclear Iron Carbonyl Complex $[\mathrm{Fe}(\mu$ Bdt $\left.)(\mathrm{CO})_{2}(\mathrm{PTA})_{2}\right]$ with Bulky Phosphine Ligands: A Model for the $[\mathrm{FeFe}]$ Hydrogenase Enzyme Active Site with an Inverted Redox Potential. Dalton Trans. 2017, 46, 10050-10056.

(45) Pandey, I. K.; Mobin, S. M.; Deibel, N.; Sarkar, B.; KaurGhumaan, S. Diiron Benzenedithiolate Complexes Relevant to the
[FeFe] Hydrogenase Active Site. Eur. J. Inorg. Chem. 2015, 28752882.

(46) Pandey, I. K.; Natarajan, M.; Faujdar, H.; Hussain, F.; Stein, M.; Kaur-Ghumaan, S. Intramolecular Stabilization of a Catalytic [FeFe]-Hydrogenase Mimic Investigated by Experiment and Theory. Dalton Trans. 2018, 47, 4941-4949.

(47) Hasan, M. M.; Hursthouse, M. B.; Kabir, S. E.; Malik, K. M. A. Dinuclear Iron Carbonyl Complexes with Dithiolate Ligands: X-Ray Structures of $\left[\mathrm{Fe}_{2}(\mathrm{CO})_{6}\left\{\mu\right.\right.$-SCCHCHC $\left.\left.\left(\mathrm{CH}_{3}\right) \mathrm{CHCS}\right\}\right]$ and $\left[\mathrm{Fe}_{2}(\mathrm{CO})_{5}\left\{\mu\right.\right.$-SCCHCHC $\left.\left.\left(\mathrm{CH}_{3}\right) \mathrm{CHCS}\right\}\left(\mathrm{PPh}_{3}\right)\right]$. Polyhedron 2001, 20, 97-101.

(48) Li, R. X.; Liu, X. F.; Liu, T.; Yin, Y. B.; Zhou, Y.; Mei, S. K.; Yan, J. Electrocatalytic Properties of [FeFe]-Hydrogenases Models and Visible-Light-Driven Hydrogen Evolution Efficiency Promotion with Porphyrin Functionalized Graphene Nanocomposite. Electrochim. Acta 2017, 237, 207-216.

(49) Schwartz, L.; Singh, P. S.; Eriksson, L.; Lomoth, R.; Ott, S. Tuning the Electronic Properties of $\mathrm{Fe}_{2}(\mu$-Arenedithiolate $)(\mathrm{CO})_{6}-$ $\mathrm{n}\left(\mathrm{PMe}_{3}\right) \mathrm{n}(\mathrm{n}=0,2)$ Complexes Related to the $[\mathrm{FeFe}]$-Hydrogenase Active Site. C. R. Chim. 2008, 11, 875-889.

(50) Li, P.; Wang, M.; He, C.; Li, G.; Liu, X.; Chen, C.; Åkermark, B.; Sun, L. Influence of Tertiary Phosphanes on the Coordination Configurations and Electrochemical Properties of Iron Hydrogenase Model Complexes: Crystal Structures of $\left[\left(\mu-\mathrm{S}_{2} \mathrm{C}_{3} \mathrm{H}_{6}\right) \mathrm{Fe}_{2}(\mathrm{CO})_{6-\mathrm{n}} \mathrm{L}_{\mathrm{n}}\right]$ $\left(\mathrm{L}=\mathrm{PMe}_{2} \mathrm{Ph}, \mathrm{n}=1,2 ; \mathrm{PPh}_{3}, \mathrm{P}(\mathrm{OEt})_{3}, \mathrm{n}=1\right)$. Eur. J. Inorg. Chem. 2005, 2506-2513.

(51) Chong, D.; Georgakaki, I. P.; Mejia-Rodriguez, R.; SanabriaChinchilla, J.; Soriaga, M. P.; Darensbourg, M. Y. Electrocatalysis of Hydrogen Production by Active Site Analogues of the Iron Hydrogenase Enzyme: Structure/Function Relationships. Dalton Trans. 2003, 4158-4163.

(52) Mejia-Rodriguez, R.; Chong, D.; Reibenspies, J. H.; Soriaga, M. P.; Darensbourg, M. Y. The Hydrophilic Phosphatriazaadamantane Ligand in the Development of $\mathrm{H}_{2}$ Production Electrocatalysts: Iron Hydrogenase Model Complexes. J. Am. Chem. Soc. 2004, 126, 1200412014.

(53) Felton, G. A. N.; Glass, R. S.; Lichtenberger, D. L.; Evans, D. H. Iron-Only Hydrogenase Mimics. Thermodynamic Aspects of the Use of Electrochemistry to Evaluate Catalytic Efficiency for Hydrogen Generation. Inorg. Chem. 2006, 45, 9181-9184.

(54) Felton, G. A. N.; Vannucci, A. K.; Okumura, N.; Lockett, L. T.; Evans, D. H.; Glass, R. S.; Lichtenberger, D. L. Hydrogen Generation from Weak Acids: Electrochemical and Computational Studies in the $\left[\left(\mathrm{n}^{5}-\mathrm{C}_{5} \mathrm{H}_{5}\right) \mathrm{Fe}(\mathrm{CO})_{2}\right]_{2}$ System. Organometallics 2008, 27, 4671-4679.

(55) Vannucci, A. K.; Wang, S.; Nichol, G. S.; Lichtenberger, D. L.; Evans, D. H.; Glass, R. S. Electronic and Geometric Effects of Phosphatriazaadamantane Ligands on the Catalytic Activity of an [FeFe] Hydrogenase Inspired Complex. Dalton Trans. 2010, 39, 3050-3056.

(56) McCarthy, B. D.; Martin, D. J.; Rountree, E. S.; Ullman, A. C.; Dempsey, J. L. Electrochemical Reduction of Brønsted Acids by Glassy Carbon in Acetonitrile-Implications for Electrocatalytic Hydrogen Evolution. Inorg. Chem. 2014, 53, 8350-8361.

(57) Sampson, M. D.; Kubiak, C. P. Electrocatalytic Dihydrogen Production by an Earth-Abundant Manganese Bipyridine Catalyst. Inorg. Chem. 2015, 54, 6674-6676.

(58) Rountree, E. S.; Dempsey, J. L. Potential-Dependent Electrocatalytic Pathways: Controlling Reactivity with $\mathrm{p} K_{\mathrm{a}}$ for Mechanistic Investigation of a Nickel-Based Hydrogen Evolution Catalyst. J. Am. Chem. Soc. 2015, 137, 13371-13380.

(59) Morris, R. H. Estimating the Acidity of Transition Metal Hydride and Dihydrogen Complexes by Adding Ligand Acidity Constants. J. Am. Chem. Soc. 2014, 136, 1948-1959.

(60) Orthaber, A.; Karnahl, M.; Tschierlei, S.; Streich, D.; Stein, M.; Ott, S. Coordination and Conformational Isomers in Mononuclear Iron Complexes with Pertinence to the $[\mathrm{FeFe}]$ Hydrogenase Active Site. Dalton Trans. 2014, 43, 4537-4549. 
(61) DuBois, M. R.; DuBois, D. L. The Role of Pendant Bases in Molecular Catalysts for $\mathrm{H}_{2}$ Oxidation and Production. C. R. Chim. 2008, 11, 805-817.

(62) Beyler, M.; Ezzaher, S.; Karnahl, M.; Santoni, M. P.; Lomoth, R.; Ott, S. Pentacoordinate Iron Complexes as Functional Models of the Distal Iron in $[\mathrm{FeFe}]$ Hydrogenases. Chem. Commun. 2011, 47, $11662-11664$.

(63) DuBois, D. L. Development of Molecular Electrocatalysts for Energy Storage. Inorg. Chem. 2014, 53, 3935-3960.

(64) Helm, M. L.; Stewart, M. P.; Bullock, R. M.; DuBois, M. R.; DuBois, D. L. A Synthetic Nickel Electrocatalyst with a Turnover Frequency Above 100,000 s $\mathrm{s}^{-1}$ for $\mathrm{H}_{2}$ Production. Science 2011, 333, $863-866$.

(65) Sheldrick, G. M. SHELX-97 Program for Crystal Structure Solution and Refinement; University of Göttingen: Göttingen, Germany, 1997.

(66) Te Velde, G.; Bickelhaupt, F. M.; Baerends, E. J.; Fonseca Guerra, C.; Van Gisbergen, S. J. A.; Snijders, J. G.; Ziegler, T. Chemistry with ADF. J. Comput. Chem. 2001, 22, 931-967.

(67) ADF2018.105. SCM Theoretical Chemistry; Vrije Universiteit: Amsterdam, The Netherlands, 2018.

(68) Becke, A. D. Density-Functional Exchange-Energy Approximation with Correct Asymptotic Behavior. Phys. Rev. A 1988, 38, 3098-3100.

(69) Perdew, J. P.; Yue, W. Accurate and Simple Density Functional for the Electronic Exchange Energy: Generalized Gradient Approximation. Phys. Rev. B 1986, 33, 8800-8802.

(70) Becke, A. D. A New Mixing of Hartree-Fock and Local DensityFunctional Theories. J. Chem. Phys. 1993, 98, 1372-1377.

(71) Stephens, P. J.; Devlin, F. J.; Chabalowski, C. F.; Frisch, M. J. $\mathrm{Ab}$ Initio Calculation of Vibrational Absorption and Circular Dichroism Spectra Using Density Functional Force Fields. J. Phys. Chem. A. 1994, 98, 11623-11627.

(72) Grimme, S.; Ehrlich, S.; Goerigk, L. Effect of the Damping Function in Dispersion Corrected Density Functional Theory. J. Comput. Chem. 2011, 32, 1456-1465.

(73) Van Lenthe, E.; Baerends, E. J. Optimized Slater-Type Basis Sets for the Elements 1-118. J. Comput. Chem. 2003, 24, 1142-1156. (74) Klamt, A.; Schüürmann, G. COSMO: A New Approach to Dielectric Screening in Solvents with Explicit Expressions for the Screening Energy and Its Gradient. J. Chem. Soc., Perkin Trans. 2 1993, 799-805.

(75) Pye, C. C.; Ziegler, T. An Implementation of the Conductorlike Screening Model of Solvation within the Amsterdam Density Functional Package. Theor. Chem. Acc. 1999, 101, 396-408.

(76) McQuarrie, D. A.; Simon, J. D. Molecular Thermodynamics; University Science Books: Sausalito, 1991.

(77) Marenich, A. V.; Ho, J. M.; Coote, M. L.; Cramer, C. J.; Truhlar, D. G. Computational Electrochemistry: Prediction of LiquidPhase Reduction Potentials. Phys. Chem. Chem. Phys. 2014, 16, 15068-15106. 